Article

\title{
TRPV4 contributes to resting membrane potential in Retinal Müller cells: Implications in cell volume regulation ${ }^{\dagger}$
}

Vanina Netti", Juan Fernández\#, Maia Kalstein, Alejandro Pizzoni, Gisela Di Giusto, Valeria Rivarola, Paula Ford and Claudia Capurro*

\# These authors contributed equally to this work.

Laboratorio de Biomembranas, IFIBIO Houssay, CONICET-UBA, Departamento de Ciencia Fisiológicas, Facultad de Medicina, Universidad de Buenos Aires, Argentina.

"Corresponding author: Prof. Claudia Capurro, Ph.D. Laboratorio Biomembranas, IFIBIO Houssay, CONICET-UBA, Departamento de Ciencias Fisiológicas. Facultad de Medicina, Universidad de Buenos Aires. Paraguay 2155, piso 7 (1121) Buenos Aires, ARGENTINA. TEL: 5411-59509500 (ext. 2145).e-mail: capurro@retina.ar

Running Head: TRPV4 and Müller cell volume regulation

Key Words: TRPV4; Human Müller Cells; Membrane Potential; Intracellular Calcium Levels; Cell Volume Regulation.

Grant information: This work was supported by grants from Universidad de Buenos Aires, Argentina; Grant number UBACYT 20020100100648 and Consejo Nacional de Ciencia y Tecnología (CONICET), Argentina; Grant Number: PIP 0296

${ }^{\dagger}$ This article has been accepted for publication and undergone full peer review but has not been through the copyediting, typesetting, pagination and proofreading process, which may lead to differences between this version and the Version of Record. Please cite this article as doi: [10.1002/jcb.25884]

Additional Supporting Information may be found in the online version of this article.

Received 28 October 2016; Revised 12 January 2017; Accepted 13 January 2017 Journal of Cellular Biochemistry This article is protected by copyright. All rights reserved DOI 10.1002/jcb.25884 


\section{Abstract}

Neural activity alters osmotic gradients favoring cell swelling in retinal Müller cells. This swelling is followed by a regulatory volume decrease (RVD), partially mediated by an efflux of $\mathrm{KCl}$ and water. The transient receptor potential channel 4 (TRPV4), a nonselective calcium channel, has been proposed as a candidate for mediating intracellular $\mathrm{Ca}^{2+}$ elevation induced by swelling. We previously demonstrated in a human Müller cell line (MIO-M1) that RVD strongly depends on ion channel activation and, consequently, on membrane potential $\left(\mathrm{V}_{\mathrm{m}}\right)$. The aim of this study was to investigate if $\mathrm{Ca}^{2+}$ influx via TRPV4 contributes to RVD by modifying intracellular $\mathrm{Ca}^{2+}$ concentration and/or modulating $\mathrm{V}_{\mathrm{m}}$ in MIO-M1 cells. Cell volume, intracellular $\mathrm{Ca}^{2+}$ levels, and $\mathrm{V}_{\mathrm{m}}$ changes were evaluated using fluorescent probes. Results showed that MIO-M1 cells express functional TRPV4 which determines the resting $\mathrm{V}_{\mathrm{m}}$ associated with $\mathrm{K}^{+}$channels. Swelling-induced increases in $\mathrm{Ca}^{2+}$ levels was due to both $\mathrm{Ca}^{2+}$ release from intracellular stores and $\mathrm{Ca}^{2+}$ influx by a pathway alternative to TRPV4. TRPV4 blockage affected swelling-induced biphasic response (depolarization-repolarization), suggesting its participation in modulating $\mathrm{V}_{\mathrm{m}}$ changes during RVD. Agonist stimulation of $\mathrm{Ca}^{2+}$ influx via TRPV4 activated $\mathrm{K}^{+}$channels hyperpolarizing $\mathrm{V}_{\mathrm{m}}$ and accelerating RVD. We propose that TRPV4 forms a signaling complex with $\mathrm{Ca}^{2+}$ and/or voltagedependent $\mathrm{K}^{+}$channels to define resting $\mathrm{V}_{\mathrm{m}}$ and $\mathrm{V}_{\mathrm{m}}$ changes during RVD. TRPV4 involvement in RVD depends on the type of stimuli and/or degree of channel activation, leading to a maximum $\mathrm{RVD}$ response when $\mathrm{Ca}^{2+}$ influx overcomes a threshold and activates further signaling pathways in cell volume regulation. This article is protected by copyright. All rights reserved 


\section{Introduction}

A major functional role of Müller cells is to control extracellular osmotic and ionic homeostasis in the retina (Kofuji and Newman, 2004; Bringmann et al., 2006; Reichenbach and Bringmann, 2010). During intense neural activity, retinal cells can be surrounded by a hypoosmotic environment, since light-evoked changes in the ionic composition of the extracellular space cause a decrease in osmolarity, thus favoring glial swelling (Dmitriev et al., 1999). This swelling is followed by a regulatory volume decrease response (RVD), mediated by an iso-osmotic efflux of $\mathrm{KCl}$, organic osmolytes and water through Aquaporin-4 (AQP4), a dynamic process resulting from the concerted action of volume-sensing mechanisms and intricate signaling cascades directed at initiating multiple adaptations (Hirrlinger et al., 2008; Wurm et al., 2006; Pannicke et al., 2004).

The increase of cytosolic $\mathrm{Ca}^{2+}$ concentration is a widespread consistent cellular response to hypo-osmotic swelling, with contributions from both extracellular $\mathrm{Ca}^{2+}$ influx and $\mathrm{Ca}^{2+}$ release from intracellular stores (Pasantes-Morales et al., 2006; Pasantes-Morales and Morales-Mulia, 2008). However, RVD is $\mathrm{Ca}^{2+}$-dependent in some cell types and $\mathrm{Ca}^{2+}$-independent in others. In the first cases, increases in cytosolic $\mathrm{Ca}^{2+}$ modulate $\mathrm{Ca}^{2+}$-activated $\mathrm{K}^{+}$channels, mainly large-conductance $\mathrm{Ca}^{2+}$-activated $\mathrm{K}^{+}$channels $(\mathrm{BK})$, to elicit $\mathrm{K}^{+}$efflux. In contrast, in another large number of cell types, these channels are not involved in RVD. In these cases, $\mathrm{K}^{+}$efflux occurs through other types of $\mathrm{K}^{+}$channels, such as voltage-gated $\mathrm{K}^{+}\left(\mathrm{K}_{\mathrm{v}}\right)$ channels or swelling-activated $\mathrm{K}^{+}$channels (inwardly rectifying $\mathrm{K}^{+}$channels Kir or two-pore-domain $\mathrm{K}^{+}$channels) (Stutzin and Hoffmann, 2006; Pasantes-Morales 2016). Other RVD mechanisms, such as the volume-sensitive anion channel and osmolyte efflux pathways, are also often $\mathrm{Ca}^{2+}$-independent (Pasantes-Morales et al., 2006). Though glial cells exhibit a rise in intracellular $\mathrm{Ca}^{2+}$ concentration in response to hypo-osmotic stimuli, the RVD and osmolyte fluxes involved in this process are not always $\mathrm{Ca}^{2+}$-dependent (Benfenati et al., 2011; Pasantes-Morales et al., 2006; Morales-Mulia et al., 1998; O'Connor and Kimelberg, 1993). It is therefore not surprising that the channels involved in RVD may be different, even in the same cell type, and cells may respond to a single or several signals elicited by volume change, such as depolarization, membrane stretch and/or elevation of intracellular $\mathrm{Ca}^{2+}$. 
In astrocyte glial cells, the Transient Receptor Potential Vanilloid type 4 (TRPV4), a calciumpermeable nonselective cation channel, was proposed as a mediator in the swelling-induced elevation of intracellular $\mathrm{Ca}^{2+}$ related to cell volume regulation (Butenko et al., 2012; Benfenati et al., 2011). Nevertheless, a recent study suggests that TRPV4 and $\mathrm{Ca}^{2+}$ do not seem to be essential for RVD to occur (Mola et al., 2015). Until recently, the participation of TRPV4 in the RVD of Müller glial cells was less explored. It is now reported that TRPV4 channels traduce mouse Müller cell volume increases into physiological responses (Ryskamp et al., 2014). Jo et al. (2015) proposed that water influx through the water channel AQP4 drives $\mathrm{Ca}^{2+}$ influx via TRPV4 in the glial end foot of mouse Müller cells. This regulates the expression of AQP4 and Kir4.1 $\mathrm{K}^{+}$channels and facilitates the time course and amplitude of hypotonicity-induced swelling and RVD. However, the authors concluded that TRPV4 might contribute only to adaptive volume regulation in retinal glia (Jo et al., 2015). We have recently shown in a human retinal Müller cell line (MIO-M1) that the efficiency of the RVD process depends not only on the activation of ion channels, but is also strongly modulated by concurrent changes in resting membrane potential $\left(\mathrm{V}_{\mathrm{m}}\right)$ (Fernández et al., 2013). Although Müller cells express different types of $\mathrm{K}^{+}$channels, it is well accepted that near resting $\mathrm{V}_{\mathrm{m}}$, Kir4.1 and $\mathrm{BK}$, are the major channels involved in $\mathrm{K}^{+}$homeostasis (Puro et al., 1996; Reichenbach and Bringmann, 2010). Since TRPV4 functionally couples to $\mathrm{Ca}^{2+}$-sensitive $\mathrm{K}^{+}$ channels in many tissues (White et al., 2016; Jo et al., 2015; Ma et al., 2013; Sullivan and Earley, 2013; Early et al., 2005), it is likely that $\mathrm{Ca}^{2+}$ influx via TRPV4 may contribute to RVD response by altering intracellular $\mathrm{Ca}^{2+}$ concentration and/or by modulating $\mathrm{V}_{\mathrm{m}}$. Therefore, the aim of this study was to further investigate the participation of TRPV4 in the RVD response using a human Müller cell line. We propose that in MIO-M1 cells TRPV4 forms a signaling complex with $\mathrm{Ca}^{2+}$ and/or voltage-dependent $\mathrm{K}^{+}$channels to define not only resting $\mathrm{V}_{\mathrm{m}}$ but also changes in $\mathrm{V}_{\mathrm{m}}$ that occur during RVD. The contribution of TRPV4 to RVD depends on the type of stimuli and/or degree of channel activation, with a maximum RVD response when $\mathrm{Ca}^{2+}$ influx overcomes a threshold and activates additional signaling pathways for cell volume regulation. 


\section{Materials and Methods}

\section{Cell Cultures}

The MIO-M1 cell line (kindly provided by Dr. Astrid Limb, University College London, London, UK) is a spontaneously immortalized retinal Müller glial cell line, originated from human retina, that retains many characteristics of Müller cells (Limb et al., 2002). Cells were grown as monolayers in the presence of Dulbecco's Modified Eagle Medium (DMEM) / glutamax supplemented with 10\% fetal bovine serum (FBS), containing $5 \mu \mathrm{g} / \mathrm{ml}$ streptomycin and $5 \mathrm{U} / \mathrm{ml}$ penicillin at $37^{\circ} \mathrm{C}$ in a humidified atmosphere containing $5 \% \mathrm{CO}_{2}$. Cells were routinely subcultured every week, and those to be studied were grown on coverslips during 3-4 days before recording.

For immunofluorescence and functional studies, MIO-M1 cells were seeded on glass coverslips (diameter $1.2 \mathrm{~cm}$ ) at $5-10 \times 10^{3}$ cells $/ \mathrm{ml}$ densities for 48 hours and then subjected to different experimental conditions.

\section{Measurement of Cell Volume Changes, RVD and Intracellular $\mathrm{Ca}^{2+}$}

By using the $\mathrm{Ca}^{2+}$-sensitive dye Fura-2 $\mathrm{AM}$ and recording at the $\mathrm{Ca}^{2+}$-sensitive $(380 \mathrm{~nm})$ and -insensitive (358 nm, isosbestic) wavelengths, we simultaneously recorded changes in cell volume and $\left[\mathrm{Ca}^{2+}\right]_{i}$ in single cells. MIO-M1 cells grown on coverslips were mounted on a chamber, incubated in $14 \mu \mathrm{M}$ Fura 2-AM (Molecular Probes Inc) for 60 minutes at $37^{\circ} \mathrm{C}$ and then washed to remove excess dye. To prevent dye compartmentalization upon loading, Pluronic F127 (0.2\%) (Molecular Probes Inc) was used to dissolve the Fura 2-AM dye. The coverslips were again incubated in the experimental buffer for 15 minutes before the experiments. The chamber was placed on the stage of a Nikon TE-200 epifluorescence inverted microscope (Nikon Planfluor 40X oil immersion objective lens) as previously described (Ford et al., 2005). Fluorescence was collected from a small circular region (pinhole) of $1-3 \%$ of the total area of the cell, localized in the central region of the cell. $\mathrm{F}$ was inversely proportional to the external osmolarity and showed a linear correlation with the relative external osmolarity. The coverslips were incubated in the experimental buffer at $20^{\circ} \mathrm{C}$ for at least $15 \mathrm{~min}$ before the experiment. Fluorescence data were acquired every 10 seconds at $20^{\circ} \mathrm{C}$ using a charge coupled device camera (Hamamatsu C4742- 
95) connected to a computer with the Metafluor data acquisition software (Universal Imaging Corporation, PA). During experiments, bathing solution was exchanged by aspirating the media and adding new media.

As previously reported, changes in cell volume were read from the fluorescence intensity recorded at the isosbestic wavelength of $358 \mathrm{~nm}$ and changes in $\left[\mathrm{Ca}^{2+}\right]_{i}$ were obtained from the ratio of 358/380 ( $R_{t} / R_{0}$ Fura-2) (Altamirano et al., 1998; Mualem et al., 1992). For calibration, cells were sequentially exposed to solutions with different osmolalities and relative fluorescence $\left(F_{t} / F_{0}\right)$ was recorded. $F_{0}$ represents the signal obtained from each pinhole when placed in equilibrium with an iso-osmotic medium with an osmolality $\mathrm{OsM}_{0}(300 \mathrm{mOsM}) . F_{t}$ is the fluorescence from the same region at time $t$, when placed in equilibrium with a solution with an osmolality of OsM $\mathrm{M}_{\mathrm{t}}$ (range: 200 to $400 \mathrm{mOsM})$. A linear relationship between $\mathrm{F}_{0} / \mathrm{F}_{\mathrm{t}}$ and the relative external osmolality $\left(\mathrm{OsM}_{0} / \mathrm{OsM}_{\mathrm{t}}\right)$ was obtained (Supplementary Figure 1). Changes in cell volume were calculated as follows:

$$
\frac{V}{V_{0}}=\frac{\left(\frac{F_{0}}{F_{t}}\right)-f_{b}}{1-f_{b}}
$$

where $V$ is cell volume at time $t, V_{0}$ is cell volume at $t=0$ and $F_{0} / F_{t}$ is relative fluorescence. The relative background $\left(f_{b}\right)$ is the $y$ intercept of a plot of $F_{0} / F_{t}$ versus $\mathrm{OsM}_{0} / \mathrm{OsM}_{\mathrm{t}}$ and represents the relative fluorescence distributed in the intracellular compartments, which is not sensitive to osmotic changes.

RVD after cell exposure to a hypo-osmotic medium was calculated by the following equation:

$$
R V D_{t}=\left[\frac{\left(\frac{V}{V_{0}}\right)_{\max }-\left(\frac{V}{V_{0}}\right)_{t}}{\left(\frac{V}{V_{0}}\right)_{\max }-1}\right] \times 100
$$

where $\left(V / V_{0}\right)_{\max }$ is the maximal value of $\mathrm{V} / \mathrm{V}_{0}$ attained during hypo-osmotic swelling (peak), and $\left(V / V_{0}\right)_{t}$ represents the value of $\mathrm{V} / \mathrm{V}_{0}$ observed at time $t . R V D_{t}$ thus denotes the magnitude of volume regulation at time $t$, with $100 \%$ RVD indicating complete volume regulation and $0 \%$ RVD indicating no volume regulation.

\section{Measurement of Membrane Voltage Changes}


Transmembrane potential was measured using bis-(1,3-dibutylbarbituric acid) trimethine oxonol (DIBAC 4 (3), Molecular Probes), a slow response anionic dye, whose emission has been shown to be independent of cell volume changes, as previously used for MIO-M1 cells (Fernández et al., 2013). The intracellular concentration of $\operatorname{DIBAC}_{4}(3)$ depends on $\mathrm{V}_{\mathrm{m}}$ following a Nernstian distribution (Brauner et al., 1984; Epps et al., 1994). Cells were loaded with $2.5 \mu \mathrm{M} \mathrm{DIBAC}_{4}(3)$ for 15 minutes at $20^{\circ} \mathrm{C}$ and placed on the stage of the same microscope described in the previous section. Excitation wavelength was $490 \mathrm{~nm}$. Emitted light (above $520 \mathrm{~nm}$ ) was recorded at 10 second intervals. Fluorescence intensity was monitored until it reached stable values before starting the experiments. Fluorescence intensity changes after interventions were relativized to stationary values $\left(F_{0} / F_{t}\right)$ and data were corrected for background noise and drift.

MIO-M1 resting $V_{m}$ is $-63.1 \pm 2.3 \mathrm{mV}$ as previously reported (Fernández et al., 2013). 1\% changes in fluorescence correspond to a $V_{m}$ variation of $2.2 \mathrm{mV}$, as calculated from the mean calibration curve $(0.0045 \pm 0.002, X \pm S D, n=58)$.

\section{Western blotting studies}

Confluent MIO-M1 cells were washed three times in cold PBS and were incubated for 30 min at $4^{\circ} \mathrm{C}$ in a cold lysis buffer containing $150 \mathrm{mM} \mathrm{NaCl}, 20 \mathrm{mM}$ Tris/HCl, $\mathrm{pH}$ 7.5, $5 \mathrm{mM}$ EDTA, 1\% Triton 100, $1 \mathrm{mM}$ PMSF, $5 \mu \mathrm{g} / \mathrm{ml}$ aprotinin, $10 \mu \mathrm{g} / \mathrm{ml}$ antipain, $10 \mu \mathrm{g} / \mathrm{ml}$ leupeptin and $10 \mu \mathrm{g} / \mathrm{ml}$ pepstatin. Cells were then collected with a rubber scraper, homogenized and sonicated. Cell lysates were subjected to electrophoresis in $8 \%$ SDS-polyacrylamide gel (Bio-Rad), transferred to a nitrocellulose membrane (Bio-Rad) and blocked 1 hour with $5 \%$ non-fat dried skimmed milk in PBS-T (80 mMNa $\mathrm{HPO}_{4}, 20 \mathrm{mMNaH}_{2} \mathrm{PO}_{4}, 100 \mathrm{mM} \mathrm{NaCl}$ and 0.1\% Tween 20, pH 7.5). Membranes were incubated with the rabbit polyclonal TRPV4 antibody (1/1000), generated against a peptide corresponding to amino acids 853-871 of rat TRPV4, (Alomone Labs, \#ACC-034) overnight at $4^{\circ} \mathrm{C}$. The blots were then washed and incubated $1 \mathrm{~h}$ at room temperature with a goat anti-rabbit IgG conjugated to horseradish peroxidase (dilution 1:7500; Sigma-Aldrich St. Louis, MO, U.S.A). Membranes were visualized using the chemiluminescence method (SuperSignal Substrate, Pierce) and captured on a Gbox (Syngene, Frederick, MD). 


\section{Immunofluorescence Assays}

Colocalization of TRPV4 and the specific plasma membrane marker Alexa Fluor 488conjugated wheat germ agglutinin (WGA; Molecular Probes) were performed. Cells were first stained with WGA, at $4^{\circ} \mathrm{C}$ for 30 minutes to label the surface glycoproteins of the plasma membrane. Then, cells were fixed in $3 \%$ paraformaldehyde for $30 \mathrm{~min}$, washed with PBS and neutralized with $\mathrm{NH}_{4} \mathrm{Cl}$ for 30 min. Cells were permeabilized for 30 min with $0.2 \%$ Triton $\mathrm{X}-100$ at room temperature and washed with PBS. Samples were blocked with $1 \%$ Bovine Serum Albumin (BSA) and incubated with anti-TRPV4 (1/1500; Alomone Labs, \#ACC-034) overnight at $4^{\circ} \mathrm{C}$. Next, cells were washed and incubated with Cy3-conjugated goat anti-rabbit $\lg G$ (1/200, Jacson Immuno, 111-165-003) for $2 \mathrm{~h}$ at room temperature. Coverslips were mounted with Vectashield mounting medium.

Images were captured using confocal Olympus FV1000 microscope and digitized. Fluorescence intensity was quantified per cell, identified by Hoechst nuclei staining. Ten fields were analyzed per experiment and quantified by densitometric analysis using Image $\mathrm{J}$-software. Since plasma membrane TRPV4 expression was low, to identify its presence, we created a mask of plasma membrane as previously described (Janecki et al., 2000). Briefly, WGA images were binarized so that the signal from WGA was ascribed the value of "1" and the rest of the image was ascribed the value of "0". The Boolean logical operation "AND" was then performed on the corresponding images, representing signals from TRPV4-Cy3 and from WGA (binary mask). This resulted in generation of a new image (shown in yellow in the figures) in which only the TRPV4Cy3 fluorescent signal corresponding to the membrane was present. Images were also analyzed by using colocalization tools and estimated using the M2 superposition coefficient of Manders (SCM), which measures the fraction of WGA that overlaps TRPV4 signal, and is described by the following equation

$$
S C M=\frac{\sum_{i}\left(R_{i} x G_{i}\right)}{\sqrt{\sum_{i} R_{i}{ }^{2} x G_{i}^{2}}}
$$

A value of 1 indicates $100 \%$ of superposition between signals of colocalized pixels, while a value of 0 indicates absence of colocalization. 


\section{Solutions and Chemicals}

For functional experiments, cells were first set for at least 10 minutes in an external isoosmotic solution containing (mM): $126 \mathrm{NaCl} ; 5,5 \mathrm{KCl} ; 2,5 \mathrm{CaCl}_{2} ; 1,25 \mathrm{MgCl}_{2} ; 20$ Hepes and 10 Glucose (Osmolarity: $299 \pm 2$ mOsM). Calcium-free solutions were made by adding EGTA (1 mM) and replacing $\mathrm{CaCl}_{2}$ by $\mathrm{MgCl}_{2}$. Experiments varying extracellular $\mathrm{K}^{+}$concentration were done by replacing $\mathrm{NaCl}$ with $\mathrm{KCl}$. Hypo-osmotic solutions were prepared from iso-osmotic solution by the removal of $\mathrm{NaCl}$ (Osmolarity: $200 \pm 2$ mOsM). All solutions were titrated to $\mathrm{pH} 7.40$ using $\mathrm{NaOH}$ (Sigma-Aldrich), and osmolalities were routinely measured by a pressure vapor osmometer (Wescor).

In some experiments, $1 \mathrm{mM} \mathrm{BaCl} ; 21 \mathrm{mM}$ Tetraethylammonium (TEA) and $0.2 \mu \mathrm{M}$ Apamin were used to block $\mathrm{K}^{+}$channels. TRPV4 activation or inhibition were tested with $10 \mu \mathrm{M}$ of TRPV4 specific activator $4 \alpha$-Phorbol-12,13-didecanoate (4 $\alpha$-PDD) and $10 \mu \mathrm{M}$ TRPV4 specific inhibitor RN1734, respectively. Since in the presence of the RN1734 we identified up to a $10 \%$ change in fluorescence levels, we considered this as a threshold for response to $4 \alpha$-PDD. Additional experiments were performed using $3 \mathrm{nM}$ of TRPV4 specific agonist GSK1016790A (GSK101) and 0,5 nM of TRPV4 specific antagonist HC-067047 (HC-06). Finally, $1 \mu \mathrm{M}$ of endoplasmic reticulum (ER) $\mathrm{Ca}^{2+}$ ATPase inhibitor Thapsigargin (TG) was used to deplete intracellular $\mathrm{Ca}^{2+}$ stores. All drugs were purchased from Sigma-Aldrich. Cells were pre-incubated in an iso-osmotic extracellular solution containing drugs or vehicle (DMSO). $1 \mathrm{mM}$ Fura-2 and $0.6 \mathrm{mM} \mathrm{DIBAC}_{4}(3)$ stock solutions were prepared in DMSO and stored at $-20^{\circ} \mathrm{C}$ until used.

\section{Statistics}

Values are reported as mean \pm SEM, and $n$ is the number of cells evaluated in each condition. Student's t test for unpaired data was used according to each protocol; $p<0.05$ was considered a significant difference. 


\section{Results}

\section{MIO-M1 cells express functional TRPV4 in the plasma membrane}

Using western blot and immunofluorescence assays, the first set of experiments evaluated TRPV4 expression and plasma membrane localization in MIO-M1 cells. Western blot analysis revealed a band of $\sim 100 \mathrm{kDa}$, corresponding to TRPV4 (Figure 1A). Figure 1B shows a representative immunofluorescence experiment, with anti-TRPV4 antibodies (red) and the cell membrane marker WGA (green), revealing a large intracellular TRPV4 signal and a minor fraction of the stain that co-localizes with WGA (yellow). To test whether this small plasma membrane TRPV4 expression had functional significance, intracellular $\mathrm{Ca}^{2+}$ levels were monitored by videomicroscopy with Fura-2 ratio, using the TRPV4 specific activator, 4a-PDD. Addition of $10 \mu \mathrm{M}$ $4 \alpha-P D D$ elicited a robust and transient increase in intracellular $\mathrm{Ca}^{2+}$ levels in $72 \pm 5 \%$ of cells (Figure $1 \mathrm{C}$ ). This effect was eliminated in the absence of external $\mathrm{Ca}^{2+}$ (Figure 1D) or in cells pretreated with $10 \mu \mathrm{M}$ RN1734, a selective TRPV4 antagonist (Figure 1E). Similar results were obtained using a structurally different agonist GSK-1016790A (GSK101, 3 nM) or the antagonist HC-067047 (HC-06, 0.5 nM) (Figure 1F). Altogether, molecular and functional results confirmed the expression of active TRPV4 channels in MIO-M1 cells.

\section{TRPV4 contributes to resting membrane potential in MIO-M1 cells}

Our previous studies in Müller cells, showed that RVD response is strongly modulated by changes in the electrochemical gradient for $\mathrm{K}^{+}$and $\mathrm{Cl}^{-}$and, thus, by $\mathrm{V}_{\mathrm{m}}$ (Fernandez et al., 2013). Keeping in mind that the high $\mathrm{K}^{+}$permeability of the plasma membrane is the basis of the very negative resting $\mathrm{V}_{\mathrm{m}}$ of Müller cells and that TRPV4 plays a key role in modulating $\mathrm{Ca}^{2+}$-activated $\mathrm{K}^{+}$ channels in a variety of cell types, we investigated the putative contribution of TRPV4 in modulating the resting $\mathrm{V}_{\mathrm{m}}$ in MIO-M1 cells. Cells were loaded with $\mathrm{DIBAC}_{4}(3)$ and $\mathrm{V}_{\mathrm{m}}$ was monitored by videomicroscopy before and after the addition of $10 \mu \mathrm{M}$ RN1734 or different blockers of $\mathrm{K}^{+}$channels: $\mathrm{i}-1 \mathrm{mM} \mathrm{BaCl}_{2}$; ii- $1 \mathrm{mM}$ TEA (a concentration shown to be selective for $\mathrm{BK}$ channels in Müller cells) or iii- $0.2 \mu \mathrm{M}$ Apamin, a blocker of SK channels (Reichenbach \& Bringmann, 2010). Figure $2 \mathrm{~A}$ shows the time course of $\mathrm{F}_{t} / \mathrm{F}_{0} \mathrm{DIBAC}_{4}(3)$ of MIO-M1 cells under iso- 
osmotic conditions, where TRPV4 inhibition elicited a robust plasma membrane depolarization. As expected, Figure 2B illustrates that incubation of cells with increasing concentrations of external $\mathrm{K}^{+}$ induced $V_{m}$ depolarization in a concentration-dependent manner, but the slope of this response was significantly decreased in the presence of RN1734, suggesting that TRPV4 modulates $\mathrm{K}^{+}$ permeability. As depicted in Figure 2C, plasma membrane depolarization was observed not only

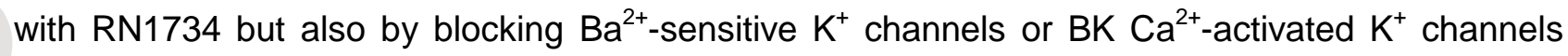
with TEA. In contrast, inhibition of $\mathrm{SK} \mathrm{Ca}^{2+}$-activated $\mathrm{K}^{+}$channels with apamin did not modify $\Delta \mathrm{F}_{\mathrm{t}} / \mathrm{F}_{0}$, dismissing the contribution of these channels to resting $\mathrm{V}_{\mathrm{m}}$. Altogether these data strongly suggest that TRPV4 may contribute to resting $V_{m}$ in Müller cells by a functional interaction with $\mathrm{Ca}^{2+}$ and/or $\mathrm{V}_{\mathrm{m}}$-sensitive $\mathrm{K}^{+}$channels.

\section{TRPV4 modulates $V_{m}$ changes occurring during RVD}

We next investigated the contribution of TRPV4 to changes in cytosolic $\mathrm{Ca}^{2+}$ concentration, $\% \mathrm{RVD}_{10}$ and $\mathrm{V}_{\mathrm{m}}$ after hypo-osmotic swelling in MIO-M1 cells. First we evaluated if the plasma membrane localization of TRPV4 was altered after cell exposure to a hypo-osmotic media $(\Delta \mathrm{OsM} \pm$ $100 \mathrm{mOsM}$ ), as described in other systems (Galizia et al., 2012). Figure 3A shows that there were no changes in TRPV4 signal after 10 minutes of hypo-osmotic shock (Fluorescence intensity per cell, red channel, ISO: $889.3 \pm 80.4$ vs HYPO $822.0 \pm 55.6,15-20$ cells of $7-11$ fields, $n=3$ experiments, NS) or in the fraction of TRPV4 that co-localizes with the plasma membrane marker WGA (yellow) in these experimental conditions (Mander's coefficient, Plasma Membrane TRPV4 vs. WGA: ISO $0.283 \pm 0.019$ vs. HYPO $0.325 \pm 0.024,15-20$ cells of $7-11$ fields, $n=3$ experiments, $N S)$. Figure 3B shows the time course of relative changes in $\mathrm{Ca}^{2+}$ levels $\left(\mathrm{R}_{t} / \mathrm{R}_{0}\right.$ Fura-2) when cells were exposed to the hypo-osmotic media. It can be observed that cell swelling led to an increase in $\mathrm{Ca}^{2+}$ levels that was not affected by the presence of $10 \mu \mathrm{M}$ RN1734 (Figure 3B insert), suggesting that TRPV4 does not contribute to this change in $\mathrm{Ca}^{2+}$ levels. In addition, Figures $3 \mathrm{C}$ illustrates that neither the kinetics of relative cell volume changes $\left(\mathrm{V} / \mathrm{V}_{0}\right)$ nor cell volume regulation (insert, $\left.\% R V D_{10}\right)$ were affected by TRPV4 blockage. However, in Figure $4 \mathrm{~A}$ we show that the swellinginduced biphasic response (depolarization-repolarization) was partially absent in the presence of RN1734, suggesting the contribution of TRPV4 to these changes. Moreover, while swelling- 
induced depolarization was not affected by $\mathrm{K}^{+}$channels blockers, the magnitude of the repolarization was significantly reduced by $\mathrm{Ba}^{2+}$ and TEA to similar levels as with $\mathrm{RN} 1734$, but not by Apamin (Figure 4B).

All these results strongly suggest that even if TRPV4 is not involved in the hypo-osmoticinduced $\mathrm{Ca}^{2+}$ increase, it contributes to modulate changes in $\mathrm{V}_{\mathrm{m}}$ that occur during RVD almost certainly associated with major $\mathrm{K}^{+}$channels expressed in Müller cells, Kir4.1 and BK.

\section{Intracellular $\mathrm{Ca}^{2+}$ stores play a fundamental role in $\mathrm{RVD}$ response}

Since an increase in cytosolic $\mathrm{Ca}^{2+}$ concentration may be attributed to both extracellular $\mathrm{Ca}^{2+}$ influx and $\mathrm{Ca}^{2+}$ release from intracellular stores, we further investigated the origin of cell swellinginduced $\mathrm{Ca}^{2+}$ increase in MIO-M1 cells. Figure $6 \mathrm{~A}$ shows that the kinetics of intracellular $\mathrm{Ca}^{2+}$ increase during the hypo-osmotic shock $(\Delta \mathrm{OsM} \pm 100 \mathrm{mOsM})$ was notably modified in the absence of external $\mathrm{Ca}^{2+}$. In fact, in a $\mathrm{Ca}^{2+}$-free solution, the swelling-induced $\mathrm{Ca}^{2+}$ increase was transient and significantly reduced in comparison to control conditions (Figure 5A, insert), suggesting that intracellular $\mathrm{Ca}^{2+}$ changes induced by hypotonicity depend, at least partially, on extracellular $\mathrm{Ca}^{2+}$. However, Figure 5B shows that external $\mathrm{Ca}^{2+}$ removal did not affect the kinetics of $\mathrm{V} / \mathrm{V}_{0}$ nor cell volume regulation response $\left(\% \mathrm{RVD}_{10}\right)$, as compared to control conditions. Afterwards, we evaluated whether intracellular $\mathrm{Ca}^{2+}$ stores participate in cell volume regulation. With that aim, we treated cells with thapsigargin (TG), a non-competitive inhibitor of the endoplasmic reticulum (ER) $\mathrm{Ca}^{2+}$-ATPase (SERCA), which causes the depletion of intracellular $\mathrm{Ca}^{2+}$ stores. Figure $5 \mathrm{C}$ shows that in a $\mathrm{Ca}^{2+}$-free solution, TG induced a transient increase in Fura-2 $\mathrm{R}_{t} / \mathrm{R}_{0}$ and then $\mathrm{Ca}^{2+}$ levels returned to basal values, as cells are unable to induce a $\mathrm{Ca}^{2+}$ entry to refill ER stores. In contrast, in the presence of external $\mathrm{Ca}^{2+}$, TG treatment induces a putative store-operated $\mathrm{Ca}^{2+}$ Entry (SOCE) evidenced by a sustained increase in intracellular $\mathrm{Ca}^{2+}$ levels. The cells subsequent exposure to a hypo-osmotic shock $(\triangle \mathrm{OsM} \pm 100 \mathrm{mOsM})$, in the presence of $\mathrm{TG}$ but in the absence of extracellular $\mathrm{Ca}^{2+}$, caused a significant decreased in intracellular $\mathrm{Ca}^{2+}$ levels (Figure $5 \mathrm{C}$ insert). However, in the presence of extracellular $\mathrm{Ca}^{2+}$, TG maintained intracellular $\mathrm{Ca}^{2+}$ levels always higher than basal levels (Figure $6 \mathrm{C}$ insert). Interestingly, Figure 5D shows that the kinetics of $\mathrm{V} / \mathrm{V}_{0}$

was also quite different with TG treatment in the presence or absence of external $\mathrm{Ca}^{2+}$. TG This article is protected by copyright. All rights reserved 
significantly enhanced RVD as compared to control conditions in a $\mathrm{Ca}^{2+}$ containing solution, but this response was almost completely impaired in the absence of external $\mathrm{Ca}^{2+}$ (Figure 5D insert). Altogether, these results propose that swelling-induced increase in $\mathrm{Ca}^{2+}$ levels are due to both $\mathrm{Ca}^{2+}$ entry from extracellular media and $\mathrm{Ca}^{2+}$ release from ER stores. However, only endogenous $\mathrm{Ca}^{2+}$ stores play a key role in MIO-M1 cell volume regulation.

\section{Agonist-induced activation of TRPV4 enhance RVD response}

Since the osmotic swelling-induced increase in $\mathrm{Ca}^{2+}$ levels in MIO-M1 cells was small ( 4-5 $\%)$, we tested if activation of TRPV4 by an alternative pathway may contribute to modulate RVD. Therefore, to measure intracellular $\mathrm{Ca}^{2+}$ levels and RVD we stimulated TRPV4 with $10 \mu \mathrm{M}$ of $4 \alpha-$ PDD prior to the hypo-osmotic shock. Figures $6 \mathrm{~A}$ shows that the increase in intracellular $\mathrm{Ca}^{2+}$ levels after TRPV4 activation was not significantly augmented by the exposure of cells to a hypoosmotic shock, but this huge rise in intracellular $\mathrm{Ca}^{2+}$ produced a rapid cell volume recovery with the consequent increase in $\% \mathrm{RVD}_{10}$ (Figure $6 \mathrm{~B}$ and insert). These changes in $\mathrm{Ca}^{2+}$ and $\mathrm{RVD}$ responses were completely reverted in the absence of external $\mathrm{Ca}^{2+}$ (Figure $6 \mathrm{C}$ and $\mathrm{D}$ ). In addition, Figure $7 \mathrm{~A}$ illustrates that $4 \alpha-\mathrm{PDD}$ induced a hyperpolarization in iso-osmotic conditions. The changes in $\mathrm{V}_{\mathrm{m}}$ evoked by the osmotic swelling (depolarization-repolarization) did not occur in the presence of $4 \alpha-$ PDD which provoked a higher hyperpolarization. TRPV4-agonist induced hyperpolarization was prevented in the presence of $\mathrm{K}^{+}$-channels blockers $\mathrm{Ba}^{2+}$ and TEA (Figure 7B).

Altogether, these results indicate that selective activation of TRPV4 during hypo-osmotic shock with the agonist $4 \alpha-P D D$ causes a larger $\mathrm{Ca}^{2+}$ influx, activating $\mathrm{K}^{+}$channels, then, hyperpolarizing cells, accelerating the RVD response.

\section{Discussion}

The present work provides new insights regarding the contribution of TRPV4 channels to RVD response in retinal human Müller cells (MIO-M1 cells). We observed the expression of a small fraction of TRPV4 at the plasma membrane, but also a large intracellular TRPV4 signal. This article is protected by copyright. All rights reserved 
However, the activation of TRPV4 induced huge increases in $\mathrm{Ca}^{2+}$ levels, demonstrating that functional TRPV4 channels are present in the plasma membrane of MIO-M1 cells. Interestingly, five splice variants have been described for human TRPV4 (bands migrating at 86-100 kDa), some of which lack Ankyrin domains and are retained intracellularly (Arniges et al., 2006). However, we detected a single isoform of TRPV4 at $\sim 100 \mathrm{kDa}$ in MIO-M1 cell line. Whether intracellular localization is because TRPV4 appears in these compartments as intermediates of biosynthetic pathways or if they are active participants in signal transduction and/or membrane trafficking, as previously reported (Dong et al., 2010; White et al., 2016), must be further investigated.

We demonstrate that TRPV4 contributes to define the resting $V_{m}$ of Müller cells since specific blockage of the channel induced plasma membrane depolarization, indicating that TRPV4 is a tonically-active channel. Given that inhibition of TRPV4-mediated $\mathrm{Ca}^{2+}$ currents should lead per se to membrane hyperpolarization, and not to the observed depolarization, we hypothesize that in Müller cells TRPV4 works in concert with $\mathrm{K}^{+}$channels, just as it does in other systems (Ma et al., 2013; Sullivan and Earley, 2013; Early et al, 2005). Even if Müller cells express different types of $\mathrm{K}^{+}$channels, such as voltage-gated $\mathrm{K}^{+}$channels and $\mathrm{Ca}^{2+}$-activated $\mathrm{K}^{+}$channels, it is well accepted that at the resting $\mathrm{V}_{\mathrm{m}}, \mathrm{K}^{+}$permeability is mediated by $\mathrm{Ba}^{2+}$-sensitive inwardly rectifying $\mathrm{K}^{+}$ channels (Kir4.1), which are key players in retinal $\mathrm{K}^{+}$homeostasis along with BK channels (Puro et al., 1996). Kir4.1 and BK channels are well discernible due to their different electrophysiological properties (Reichenbach and Bringmann, 2010). In Müller cells, BK channels are mainly activated by an increase in the free $\mathrm{Ca}^{2+}$ level at the intracellular side of the plasma membrane as well as by membrane depolarization. We provide evidence that blockade of $\mathrm{K}^{+}$channels with $\mathrm{Ba}^{2+}$ evoked a depolarization similar to that induced by TRPV4 inhibition, and TEA also induced a depolarization, but to a lesser extent than $\mathrm{Ba}^{2+}$. Therefore, it is likely that TRPV4, in concert with activation of one or more $\mathrm{K}^{+}$channels, contributes to define resting $\mathrm{V}_{\mathrm{m}}$ in MIO-M1 cells. We propose that $\mathrm{Ca}^{2+}$ influx via TRPV4 may activate $\mathrm{Ca}^{2+}$-dependent $\mathrm{BK}$ channels but at the same time $\mathrm{Ca}^{2+}$ influx induces a transient depolarization that, in turn, may increase Kir4.1 outwardly directed $\mathrm{K}^{+}$currents at $\mathrm{V}_{\mathrm{m}}$ more positive than resting $V_{m}$ in Müller cells (Reichenbach and Bringmann, 2010).

Our data also demonstrates that, as in many other cell types, MIO-M1 cells had increased intracellular $\mathrm{Ca}^{2+}$ levels during osmotic swelling. However, this increase was slight ( $\left.5 \%\right)$ and This article is protected by copyright. All rights reserved 
occurred through a pathway other than TRPV4. External $\mathrm{Ca}^{2+}$ removal significantly reduced swelling-activated increases in $\mathrm{Ca}^{2+}$ levels without affecting RVD, suggesting the contribution of RVD effectors independently of extracellular $\mathrm{Ca}^{2+}$ influx, at least in these experimental conditions. These data differ from studies on rodent Müller glia, which conclude that TRPV4 is the main mediator of hypotonic-induced $\mathrm{Ca}^{2+}$ entry (Ryskamp et al., 2014; Jo et al., 2015), but agree with the final suggestion that TRPV4 is not necessarily involved in RVD. The reasons for these discrepant results are unclear but might be due to differences between species, cell models, experimental means of detection of intracellular $\mathrm{Ca}^{2+}$ and/or size of the hypotonic stimuli. However, our results are consistent with previous data from mouse-cultured astrocytes in which the inhibition of TRPV4 or the removal of extracellular $\mathrm{Ca}^{2+}$ did not affect RVD (Mola et al., 2016; Morales-Mulia et al., 1998). Mola et al. (2016) concluded that the rapid AQP4-dependent cell swelling is the main determinant of RVD efficiency. Nevertheless, there are also reports in astrocytes showing that AQP4 is functionally coupled to TRPV4 (Benfenati et al., 2011). We did not focus our present work on evaluating the role of AQP4 association with TRPV4 during a hypotonic shock in MIO-M1 cells since our previous results showed that the removal of AQP4 from the plasma membrane affects osmotic water permeability and RVD without altering TRPV4 expression or function (unpublished results). In line with this observation, we here showed that TRPV4 activation or inhibition did not modify cell swelling kinetics, probably indicating the absence of a functional interaction between TRPV4 and AQP4 to determine RVD, as previously reported in mouse Müller cells (Jo et al., 2015). However, we cannot disregard that this interaction may occur to define other pathophysiological processes. In fact, previous reports in mouse Müller cells described that TRPV4 absence or overactivation as well as AQP4 deletion are associated with reactive gliosis and gliovascular modifications (Ryskamp et al., 2014, Nicchia et al., 2016) which are, in turn, associated with alterations in $\mathrm{Ca}^{2+}$ homeostasis.

We also suggest that a possible alternative pathway for $\mathrm{Ca}^{2+}$ increase during a hypo-osmotic challenge in MIO-M1 cells could be $\mathrm{Ca}^{2+}$ release from stores, as previously shown in astrocytes (Morales-Mulia et al., 1998; Mola et al., 2015). In fact, our data demonstrated that RVD largely depended on intracellular $\mathrm{Ca}^{2+}$ stores, probably indicating that intracellular $\mathrm{Ca}^{2+}$ release may be sufficient to elicit the RVD response and could explain the insensitivity of RVD to external $\mathrm{Ca}^{2+}$ in 
MIO-M1 cells. A recent work showed that store-operated signalling represents a major source of cytosolic $\mathrm{Ca}^{2+}$ in mouse Müller cells; however, the physiological relevance of this finding has not yet been established (Molnar et al., 2016). The likely purpose of extracellular $\mathrm{Ca}^{2+}$ entry during a hypo-osmotic challenge may be the replenishment of endogenous stores, which are depleted after swelling.

The lack of contribution of TRPV4 to the increase of $\mathrm{Ca}^{2+}$ levels under a hypo-osmotic stimulation in MIO-M1 cells does not rule out the possibility that TRPV4 may participate in RVD response when it is largely activated by agonists, as shown by other authors (Cardin et al, 2003).

We demonstrated that stimulation of $\mathrm{Ca}^{2+}$ influx via TRPV4 enhanced RVD to a greater extent than observed in control conditions. A similar response was observed when intracellular $\mathrm{Ca}^{2+}$ stores were depleted in the presence of extracellular $\mathrm{Ca}^{2+}$, activating SOCE. Finally, we found a positive correlation between changes in intracellular $\mathrm{Ca}^{2+}$ levels and \% RVD $\left(r^{2}: 0.7012 ; n=100\right.$ cells). Therefore, we propose that RVD machinery involves both $\mathrm{Ca}^{2+}$-independent and $\mathrm{Ca}^{2+}$ dependent machinery in MIO-M1 cells. When $\mathrm{Ca}^{2+}$ levels enhance over those induced by a physiological hypo-osmotic swelling, a more potent RVD takes place due to the opening of other $\mathrm{Ca}^{2+}$-activated channels. In line with this idea, there are reports in astrocytes that indicate that increasing intracellular $\left[\mathrm{Ca}^{2+}\right]$ over hypo-osmotic-induced levels by the ionophore ionomycin or by activation of G-protein coupled receptors markedly potentiates some of the osmolyte efflux pathways (Cardin et al. 2003; Vazquez Juarez et al., 2008).

Interestingly, our observation of a functional association between TRPV4 and $\mathrm{Ca}^{2+}$ and/or $\mathrm{V}_{\mathrm{m}}$-sensitive $\mathrm{K}^{+}$channels to define resting $\mathrm{V}_{\mathrm{m}}$ in MIO-M1 cells, opens the question about its contribution to the depolarization-repolarization that takes place during an osmotic shock. Our results show that cell swelling-induced depolarization was significantly reduced with TRPV4 antagonist. Since this depolarization is due to concurrent events, such as intracellular ions dilution, $\mathrm{Ca}^{2+}$ influx and/or $\mathrm{Cl}^{-}$efflux (Fernandez et al., 2013), it would be expected to be affected by reductions in the $\mathrm{K}^{+}$driving force by dilution and blocking $\mathrm{Ca}^{2+}$ influx via TRPV4. RVD-induced repolarization was inhibited to the same extent by blocking TRPV4 or blocking $\mathrm{K}^{+}$channels with $\mathrm{Ba}^{2+}$ or TEA, suggesting a functional association of TRPV4 and BK channels during RVD. This relationship was further confirmed when TRPV4 was activated by the agonist $4 \alpha$-PDD during a This article is protected by copyright. All rights reserved 
hypo-osmotic shock, which causes cell hyperpolarization, that was completely blunted by $\mathrm{Ba}^{2+}$ or TEA.

How could TRPV4 blockage affect $V_{m}$ without evoking detectable changes in the magnitude of cytosolic $\mathrm{Ca}^{2+}$ levels or in the \%RVD during the osmotic shock? We have previously demonstrated that in MIO-M1 cells, as in many other systems, only a fraction of RVD is mediated by $\mathrm{KCl}$ efflux: there is also a major component ( $70 \%)$ mediated by organic osmolyte efflux (Fernández et al., 2013; Ando et al., 2012; Pasantes-Morales et al., 1994). Therefore it is likely that hypo-osmotic-induced local changes in $\mathrm{Ca}^{2+}$ conductance mediated by TRPV4 occur close to the plasma membrane and do not affect intracellular $\mathrm{Ca}^{2+}$ levels, though they are sufficient for BK channel activation. In fact, it has been reported that in local $\mathrm{Ca}^{2+}$ microdomains, $\mathrm{Ca}^{2+}$ concentration can rapidly rise to very high levels, often up to orders of magnitude greater than bulk cytoplasmatic $\mathrm{Ca}^{2+}$, providing means for rapid and selective activation of targets closeby, such as $\mathrm{Ca}^{2+}$-activated $\mathrm{K}^{+}$channels (Parekh, 2008). Parallely, other $\mathrm{Ca}^{2+}$-dependent and independent mechanisms could be activated to evoke RVD response. Previous studies in human Müller cells have shown that RVD also depends on ATP activation of purinergic receptors P2Y, which elicits an increase in intracellular $\mathrm{Ca}^{2+}$ levels (Reichenbach \& Bringmann 2016). Moreover, it was reported that TRPV4 activation evokes ATP release in several systems (White et al., 2016). Hence, there may be a link between TRPV4 and purinergic receptor activation during RVD. Future experiments are necessary to address this issue.

In summary, our data reveal that TRPV4 in association with $\mathrm{K}^{+}$channels not only defines steady-state $V_{m}$ but also modulates changes in $V_{m}$ occurring during a hypo-osmotic shock. This functional association is mediated by $\mathrm{Ca}^{2+}$ influx via TRPV4. We also propose that the involvement of TRPV4 in RVD response depends on the type of stimuli and/or degree of channel activation, leading to a maximum RVD response when $\mathrm{Ca}^{2+}$ influx overcomes a threshold to activate further signalling pathways for cell volume regulation. Altogether, these findings add new insights into knowledge on the role of TRPV4 in the retinal Müller cells. 


\section{Acknowledgments}

The authors thank Dr. Astrid Limb (University College London, London, UK) for providing the human Müller Cell Line (MIO-M1), María Teresa Politi and Jessica Haefner for language assistance.

\section{References}

1. Altamirano J, Brodwick MS, Alvarez-Leefmans FJ. 1998. Regulatory volume decrease and intracellular $\mathrm{Ca} 2+$ in murine neuroblastoma cells studied with fluorescent probes. J Gen Physiol 112:145-60.

2. Ando D, Kubo Y, Akanuma S, Yoneyama D, Tachikawa M, Hosoya K. 2012. Function and regulation of taurine transport in Müller cells under osmotic stress. Neurochem Int 60:597-604.

3. Arniges M, Fernández-Fernández JM, Albrecht N, Schaefer M, Valverde MA. 2006. Human TRPV4 channel splice variants revealed a key role of ankyrin domains in multimerization and trafficking. J Biol Chem 281:1580-6.

4. Benfenati V, Caprini M, Dovizio M, Mylonakou MN, Ferroni S, Ottersen OP, AmiryMoghaddam M. 2011. An aquaporin-4/transient receptor potential vanilloid 4 (AQP4/TRPV4) complex is essential for cell-volume control in astrocytes. Proc Natl Acad Sci 8;108:2563-8.

5. Bräuner T, Hülser DF, Strasser RJ. 1984. Comparative measurements of membrane potentials with microelectrodes and voltage-sensitive dyes. Biochim Biophys Acta 11;771:208-16.

6. Bringmann A, Pannicke T, Grosche J, Francke M, Wiedemann P, Skatchkov SN, Osborne NN, Reichenbach A. 2006. Müller cells in the healthy and diseased retina. Prog Retin Eye Res 25:397-424.

7. Butenko O, Dzamba D, Benesova J, Honsa P, Benfenati V, Rusnakova V, Ferroni S, Anderova M. 2012. The increased activity of TRPV4 channel in the astrocytes of the adult rat hippocampus after cerebral hypoxia/ischemia. PLoS One 7:e39959. 
8. Cardin V, Lezama R, Torres-Márquez ME, Pasantes-Morales H. 2003. Potentiation of the osmosensitive taurine release and cell volume regulation by cytosolic $\mathrm{Ca} 2+$ rise in cultured cerebellar astrocytes. Glia 44:119-28.

9. Dmitriev AV, Govardovskii VI, Schwahn HN, Steinberg RH. 1999. Light induced changes of extracellular ions and volume in the isolated chick retina-pigment epithelium preparation. Vis Neurosci 16:1157-1167.

10. Dong XP, Wang X \& Xu H. 2010. TRP Channels of Intracellular Membranes. J Neurochem 113:313-328.

11. Earley S, Heppner TJ, Nelson MT, Brayden JE. 2005. TRPV4 forms a novel Ca2+ signaling complex with ryanodine receptors and BKCa channels. Circ Res 9;97:1270-9.

12. Epps DE, Wolfe ML, Groppi V. 1994. Characterization of the steady-state and dynamic fluorescence properties of the potential-sensitive dye bis-(1,3-dibutylbarbituric acid) trimethine oxonol (Dibac4(3)) in model systems and cells. Chem Phys Lipids 69:137-50.

13. Fernández JM, Di Giusto G, Kalstein M, Melamud L, Rivarola V, Ford P, Capurro C. 2013. Cell volume regulation in cultured human retinal Müller cells is associated with changes in transmembrane potential. PLoS One 8(2):e57268.

14. Ford P, Rivarola V, Chara O, Blot-Chabaud M, Cluzeaud F, Farman N, Parisi M, Capurro C. 2005. Volume regulation in cortical collecting duct cells: role of AQP2. Biol Cell 97:687-97.

15. Galizia L, Pizzoni A, Fernandez J, Rivarola V, Capurro C, Ford P. 2012. Functional interaction between AQP2 and TRPV4 in renal cells. J Cell Biochem 113:580-9.

16. Hirrlinger PG, Wurm A, Hirrlinger J, Bringmann A, Reichenbach A. 2008. Osmotic swelling characteristics of glial cells in the murine hippocampus, cerebellum, and retina in situ. $J$ Neurochem 105:1405-17. doi: 10.1111/j.1471-4159.2008.05243

17. Janecki AJ1, Janecki M, Akhter S, Donowitz M. 2000. Quantitation of plasma membrane expression of a fusion protein of $\mathrm{Na} / \mathrm{H}$ exchanger $\mathrm{NHE3}$ and green fluorescence protein (GFP) in living PS120 fibroblasts. J Histochem Cytochem 48:1479-92.

18. Jo AO, Ryskamp DA, Phuong TT, Verkman AS, Yarishkin O, MacAulay N, Križaj D. 2015. TRPV4 and AQP4 Channels Synergistically Regulate Cell Volume and Calcium Homeostasis in Retinal Müller Glia. J Neurosci 30;35:13525-37. 
19. Kofuji P, Newman EA. 2004. Potassium buffering in the central nervous system. Neuroscience 129:1045-56.

20. Limb GA, Salt TE, Munro PM, Moss SE, Khaw PT. 2002. In vitro characterization of a spontaneously immortalized human Müller cell line (MIO-M1). Invest Ophthalmol Vis Sci 43(3):864-9.

21. Ma X, Du J, Zhang P, Deng J, Liu J, Lam FF, Li RA, Huang Y, Jin J, Yao X. 2013. Functional role of TRPV4-KCa2.3 signaling in vascular endothelial cells in normal and streptozotocininduced diabetic rats. Hypertension 62:134-139.

22. Mola MG, Sparaneo A, Gargano CD, Spray DC, Svelto M, Frigeri A, Scemes E, Nicchia GP. 2016. The speed of swelling kinetics modulates cell volume regulation and calcium signaling in astrocytes: A different point of view on the role of aquaporins. Glia 64:139-54.

23. Molnár T, Yarishkin O, Luso A, Barabas P, Jones B, Marc RE, Phuong TT, Križaj D. 2016. Store-Operated Calcium Entry in Müller Glia Is Controlled by Synergistic Activation of TRPC and Orai Channels. J Neurosci 36:3184-98.

24. Morales-Mulia S, Vaca L, Hernandez-Cruz A, Pasantes-Morales H. Osmotic swelling-induced changes in cytosolic calcium do not affect regulatory volume decrease in rat cultured suspended cerebellar astrocytes. 1998. J Neurochem 71:2330-8.

25. Muallem S, Zhang BX, Loessberg PA, Star RA. 1992. Simultaneous recording of cell volume changes and intracellular $\mathrm{pH}$ or $\mathrm{Ca} 2+$ concentration in single osteosarcoma cells UMR-10601. J Biol Chem 267:17658-17664.

26. Nicchia GP, Pisani F, Simone L, Cibelli A, Mola MG, Dal Monte M, Frigeri A, Bagnoli P, Svelto M. 2016. Glio-vascular modifications caused by Aquaporin-4 deletion in the mouse retina. Exp Eye Res 146:259-68.

27. O'Connor ER, Kimelberg HK. 1993. Role of calcium in astrocyte volume regulation and in the release of ions and amino acids. J Neurosci 13:2638-50.

28. Pannicke T, landiev I, Uckermann O, Biedermann B, Kutzera F, Wiedemann P, Wolburg H, Reichenbach A, Bringmann A. 2004. A potassium channel-linked mechanism of glial cell swelling in the postischemic retina. Mol Cell Neurosci 26:493-502. 
29. Parekh AB. 2008. Ca2+ microdomains near plasma membrane Ca2+ channels: impact on cell function. J Physiol 586:3043-3054.

30. Pasantes-Morales H. Channels and Volume Changes in the Life and Death of the Cell 2016. Mol Pharmacol 90:358-370.

31. Pasantes-Morales H, Chacón E, Murray RA, Morán J. Properties of osmolyte fluxes activated during regulatory volume decrease in cultured cerebellar granule neurons. J Neurosci Res. 1994 15;37(6):720-7.

32. Pasantes-Morales H, Lezama RA, Ramos-Mandujano G, Tuz KL. 2006. Mechanisms of cell volume regulation in hypo-osmolality. Am J Med 119:S4-11.

33. Pasantes-Morales $\mathrm{H}$, Morales Mulia S. Influence of calcium on regulatory volume decrease: role of potassium channels. 2008 Nephron 86:414-27.

34. Puro DG, Yuan JP, Sucher NJ. 1996. Activation of NMDA receptor-channels in human retinal Müller glial cells inhibits inward-rectifying potassium currents. Vis Neurosci 13:319-326.

35. Reichenbach A, Bringmann A. 2010. Müller Cells in the Healthy and Diseased Retina. New York:Springer. P.35-213.

36. Reichenbach A, Bringmann A. 2016. Role of Purines in Müller Glia. J Ocul Pharmacol Ther 32:518-533.

37. Ryskamp DA, Jo AO, Frye AM, Vazquez-Chona F, MacAulay N, Thoreson WB, Križaj D. 2014. Swelling and eicosanoid metabolites differentially gate TRPV4 channels in retinal neurons and glia. J Neurosci 19;34:15689-700.

38. Stutzin A, Hoffmann EK. 2006. Swelling-activated ion channels: functional regulation in cellswelling, proliferation and apoptosis. Acta Physiol 187:27-42.

39. Sullivan MN, Earley S. 2013. TRP channel $\mathrm{Ca}(2+)$ sparklets: fundamental signals underlying endothelium-dependent hyperpolarization. Am J Physiol Cell Physiol 15;305:C999-C1008.

40. Vázquez-Juárez E, Ramos-Mandujano G, Hernández-Benítez R, Pasantes-Morales H. 2008. On the role of G-protein coupled receptors in cell volume regulation. Cell Physiol Biochem 21:1-14. 
41. White JPM, Cibelli M, Urban L, Nilius B, McGeown JG, Nagy I. 2016. TRPV4: Molecular Conductor of a Diverse Orchestra. Physiol Rev 96:911-973.

42. Wurm A, Pannicke T, landiev I, Wiedemann P, Reichenbach A, Bringmann A. 2006. The developmental expression of $\mathrm{K}+$ channels in retinal glial cells is associated with a decrease of osmotic cell swelling. Glia 54:411-23. 


\section{Legend to figures}

Figure 1: TRPV4 expression and functionality in MIO-M1 cells. A- Western blot showing TRPV4 expression. B- Representative confocal images of MIO-M1 cells immunostained for TRPV4 (Cy3, red) and for the cell plasma membrane marker WGA-Alexa Fluor 488 (green). Image showing TRPV4 expressed at the plasma membrane (PM TRPV4, yellow) generated by a mask of plasma membrane (see Methods). Scale bar, $10 \mu \mathrm{m}$. C and D- Representative recordings of intracellular $\mathrm{Ca}^{2+}$ levels with Fura-2 AM $\left(\mathrm{R}_{t} / \mathrm{R}_{0}\right.$ Fura-2) in cells exposed, at the arrow, to $10 \mu \mathrm{M} 4 \alpha-$ PDD (TRPV4 specific agonist) in the presence of $2.5 \mathrm{mM}$ of external $\mathrm{CaCl}_{2}\left(+\mathrm{Ca}^{2+}\right)$ or in the absence of external $\mathrm{Ca}^{2+}\left(0 \mathrm{Ca}^{2+}\right)$. E- Representative recordings of intracellular $\mathrm{Ca}^{2+}$ levels with Fura-2 AM in cells pretreated with $10 \mu \mathrm{M}$ RN1734 (TRPV4 antagonist), and then with $10 \mu \mathrm{M} 4 \alpha-$ PDD + $10 \mu \mathrm{M}$ RN1734 and finally removing RN1734 (Insert: enlarged y-scale to show the effects of RN1734 during the first $25 \mathrm{~min})$. F- Maximal variation in intracellular $\mathrm{Ca}^{2+}$ levels $\left(\Delta \max \mathrm{R}_{\mathrm{t}} / \mathrm{R}_{0}\right.$ Fura-2) for cells treated with vehicle, $10 \mu \mathrm{M} 4 \alpha-\mathrm{PDD}, 3 \mathrm{nM}$ GSK101, $10 \mu \mathrm{M}$ RN1734 + $10 \mu \mathrm{M} 4 \alpha-$ PDD or $0.5 \mathrm{nM} \mathrm{HC}-06+10 \mu \mathrm{M} 4 \alpha-\mathrm{PDD}$. Three independent assays were performed for each experimental condition including 19-29 cells per experiment.

Figure 2: Contribution of TRPV4 to resting membrane potential in MIO-M1 cells. $\mathrm{V}_{\mathrm{m}}$ was monitored using the dye $\operatorname{DIBAC}_{4}(3)$ under different experimental conditions. A- Representative kinetics of relative fluorescence changes, $F_{t} / F_{0} \operatorname{DIBAC}_{4}(3)$, when cells were exposed, at the arrow, to $10 \mu \mathrm{M}$ of the TRPV4 antagonist RN1734 or vehicle (DMSO). B- Slope $x 10^{-4}, \mathrm{~F}_{t} / \mathrm{F}_{0} \mathrm{DIBAC} \mathrm{C}_{4}(3) \mathrm{x}$ $\mathrm{mM}^{-1}$ : Vehicle $79.1 \pm 2.8$ vs RN1734 $48.0 \pm 4.1, \mathrm{p}<0.001, \mathrm{n}=9-18$ cells from 4 experiments. CMaximal change in fluorescence obtained after pretreatment of cells with: Vehicle, $10 \mu \mathrm{M}$ RN1734 or different blockers of $\mathrm{K}^{+}$channels ( $1 \mathrm{mM} \mathrm{BaCl}_{2} ; 1 \mathrm{mM}$ TEA or $0.2 \mu \mathrm{M}$ Apamin). Values are mean \pm SEM from 3-4 experiments including a total of $40-91$ cells; ${ }^{* * *} \mathrm{p}<0,001$ vehicle vs. RN1734 or $\mathrm{Ba}^{2+} ;{ }^{* *} \mathrm{p}<0,01$ vehicle vs. TEA.

Figure 3: Role of TRPV4 on swelling-induced $\mathrm{Ca}^{2+}$ levels and RVD.

This article is protected by copyright. All rights reserved 
MIO-M1 cells were subjected to a hypo-osmotic stress ( $\triangle \mathrm{OsM}=100 \mathrm{mOsM})$ in the presence of 10 $\mu \mathrm{M}$ RN1734 or vehicle (DMSO). Intracellular $\mathrm{Ca}^{2+}$ levels and cell volume changes were measured in cells loaded with Fura 2-AM A- Representative confocal images of cells showing TRPV4 distribution before and after 10 minutes exposure to hypo-osmotic media. Cells were immunolabeled with anti-TRPV4 (red) and the cell plasma membrane marker WGA-Alexa Fluor 488 (green). Plasma membrane fraction was obtained for TRPV4-Cy3 fluorescent signal (PM TRPV4, yellow). Scale bar, $10 \mu \mathrm{m}$. B- Kinetics of changes in relative Fluorescence $\left(R_{t} / R_{0}\right.$ Fura-2) after the hypo-osmotic shock showing that RN1734 do not affect swelling-induced $\mathrm{Ca}^{2+}$ levels increase. Insert: mean values of the percentage of intracellular $\mathrm{Ca}^{+2}$ levels increase for both experimental conditions. C- Dynamics of relative cell volume changes $\left(V / V_{0}\right)$ in the presence of RN1734 or vehicle (DMSO). Insert: mean values of $\% \mathrm{RVD}_{10}$ for both experimental conditions. Values are mean \pm SEM for $40-46$ cells of 4 independent experiments.

Figure 4: Effects of blockage of TRPV4 on swelling-induced changes in $\mathrm{V}_{\mathbf{m}}$. MIO-M1 cells were subjected to a hypo-osmotic stress $(\Delta \mathrm{OsM}=100 \mathrm{mOsM})$ in the presence of $10 \mu \mathrm{M}$ RN1734 or vehicle (DMSO). A- Representative kinetics of changes in relative fluorescence $\left(F_{t} / F_{0}\right)$ using $\mathrm{DIBAC}_{4}(3)$, when cells were exposed to the hypo-osmotic stress in both experimental conditions. B- $\Delta \mathrm{F}_{t} / \mathrm{F}_{0} \mathrm{DIBAC}_{4}(3)$ mean values of maximal fluorescence changes (Depolarization) obtained after pretreatment of cells with: $10 \mu \mathrm{M}$ RN1734 or different blockers of $\mathrm{K}^{+}$channels $\left(1 \mathrm{mM} \mathrm{BaCl} \mathrm{B}_{2} ; 1 \mathrm{mM}\right.$ TEA or $0.2 \mu \mathrm{M}$ Apamin). The magnitude of the Repolarization was assessed as the difference between $\Delta \mathrm{F}_{t} / \mathrm{F}_{0}$ at the maximum peak and $\Delta \mathrm{F}_{t} / \mathrm{F}_{0} 30$ minutes after exposure to a hypo-osmotic media. Values are mean \pm SEM for $25-47$ cells from 3-6 independent experiments ${ }^{* * *} p<0.001$ vehicle vs. RN1734, $\mathrm{Ba}^{2+}$ or TEA.

Figure 5: Contribution of extracellular and intracellular $\mathrm{Ca}^{2+}$ to RVD. MIO-M1 cells were loaded with Fura 2-AM to measure intracellular $\mathrm{Ca}^{2+}$ levels and cell volume changes. Cells were exposed to a hypo-osmotic stress ( $\triangle \mathrm{OsM}=100 \mathrm{mOsM}, \mathrm{HYPO})$ A- Kinetics of changes in relative fluorescence $\left(R_{t} / R_{0}\right.$ Fura-2) in cells subjected to a hypo-osmotic stress in the presence $\left(+\mathrm{Ca}^{2+}\right)$ or 
absence of external $\mathrm{Ca}^{2+}\left(0 \mathrm{Ca}^{2+}\right)$. Insert: mean values of the percentage of intracellular $\mathrm{Ca}^{+2}$ levels increase for both experimental conditions. Values are mean \pm SEM for 28-67 cells from 4 independent experiments, ${ }^{* * *} \mathrm{p}<0.001+\mathrm{Ca}^{2+}$ vs. $0 \mathrm{Ca}^{2+}$ B- Dynamics of relative cell volume changes in cells subjected to a hypo-osmotic in the presence $\left(+\mathrm{Ca}^{2+}\right)$ or absence of external $\mathrm{Ca}^{2+}$ $\left(0 \mathrm{Ca}^{2+}\right)$. Insert: mean values of $\% \mathrm{RVD}_{10}$ for both experimental conditions. Values are mean $\pm \mathrm{SEM}$ for $28-67$ cells from 4 independent experiments, ${ }^{\star * *} \mathrm{p}<0.001+\mathrm{Ca}^{2+}$ vs. $0 \mathrm{Ca}^{2+}$. C- To deplete intracellular $\mathrm{Ca}^{2+}$ stores, cells were first incubated with $1 \mu \mathrm{M} \mathrm{TG}$ in the presence $\left(+\mathrm{Ca}^{2+}\right)$ or in the absence of $\mathrm{Ca}^{2+}\left(\mathrm{CCa}^{2+}\right)$ followed by the hypo-osmotic shock. Insert: Percentage of intracellular $\mathrm{Ca}^{2+}$ increase 20 minutes after the addition of $1 \mu \mathrm{M}$ TG in the absence or in the presence of external $\mathrm{Ca}^{2+}\left(\mathrm{TG}+\mathrm{Ca}^{2+}\right.$ and $\mathrm{TG} 0 \mathrm{Ca}^{2+}$ respectively). Values are mean $\pm \mathrm{SEM}$ for $42-61$ cells from 3-4 independent experiments, ${ }^{* * *} \mathrm{p}<0.001 \mathrm{TG}+\mathrm{Ca}^{2+} \mathrm{Vs} \mathrm{TG} 0 \mathrm{Ca}^{2+}$. D- Kinetics of relative cell volume Changes $\left(\mathrm{V} / \mathrm{V}_{0}\right)$ in cells exposed to all conditions described in C. Insert: Mean values of $\% \mathrm{RVD}_{10}$ in the presence or absence of external $\mathrm{Ca}^{2+}$ when cells were incubated with $1 \mu \mathrm{M} \mathrm{TG}$ (TG $+\mathrm{Ca}^{2+}$ and TG $0 \mathrm{Ca}^{2+}$ respectively). Values are mean \pm SEM for 42-61 cells from 3-4 experiments. ${ }^{* * *} \mathrm{p}<0.001 \mathrm{TG}+\mathrm{Ca}^{2+}$ vs TG $0 \mathrm{Ca}^{2+}$.

Figure 6: Effect of TRPV4 activation on swelling-induced $\mathrm{Ca}^{2+}$ levels and RVD. Intracellular $\mathrm{Ca}^{2+}$ levels and cell volume changes were measured in cells loaded with Fura 2-AM and subjected to a hypo-osmotic stress $(\triangle \mathrm{OsM}=100 \mathrm{mOsM})$ in the presence of $10 \mu \mathrm{M} 4 \alpha$-PDD or vehicle (DMSO). A-C Representative experiments showing the kinetic of intracellular $\mathrm{Ca}^{2+}$ levels, as relative fluorescence changes $\left(F_{t} / F_{0}\right.$ Fura-2), in the presence $(A)$ or absence of external $\mathrm{Ca}^{2+}(\mathbf{C})$. B- Kinetic of cell volume changes, as relative fluorescence changes $\left(F_{t} / F_{0}\right)$, in the presence or absence of $4 \alpha-P D D$ or vehicle. D- Kinetic of cell volume changes, as relative fluorescence changes $\left(F_{t} / F_{0}\right)$, in the presence of $4 \alpha-P D D$ with $\left(+\mathrm{Ca}^{2+}\right)$ or without $\left(0 \mathrm{Ca}^{2+}\right)$ external $\mathrm{Ca}^{2+}$. Inserts in $B$ and $D$ : Mean values of $\%$ of RVD at 10 minutes after the osmotic shock $\left(\% R V D_{10}\right)$ in both experimental conditions. Values are mean \pm SEM for 40-91 cells from 3-5 independent experiments ${ }^{* *} p<0.01$ vehicle vs. $4 \alpha-P D D$ and $4 \alpha-P D D+\mathrm{Ca}^{2+}$ vs. $4 \alpha-P D D, 0 \mathrm{Ca}^{2+}$. 
Figure 7: Effects of TRPV4 activation on swelling-induced changes in $V_{m}$. MIO-M1 cells were loaded with $\mathrm{DIBAC}_{4}(3)$ and subjected to a hypo-osmotic stress $(\triangle \mathrm{OsM}=100 \mathrm{mOsM})$ in the presence of $10 \mu \mathrm{M} 4 \alpha-\mathrm{PDD}$ or vehicle (DMSO). A- Kinetics of changes in relative fluorescence $\left(F_{t} / F_{0}\right)$ when cells were exposed to a hypo-osmotic stress in the presence of $4 \alpha-P D D$ or control (vehicle). B- Mean values of maximal fluorescence changes $\left(\Delta \mathrm{F}_{t} / \mathrm{F}_{0} \operatorname{DIBAC}_{4}(3)\right)$ during the osmotic challenge in cells treated with vehicle (DMSO), $4 \alpha-P D D, 4 \alpha-P D D+\mathrm{Ba}^{2+}$ or $4 \alpha-P D D+T E A$. Values are mean \pm SEM for $40-91$ cells from $3-5$ independent experiments ${ }^{* * *} p<0.001$ vehicle vs. $4 \alpha-$ PDD and \#\#\# $p<0.0014 \alpha-P D D+C a^{2+}$ vs. $4 \alpha-P D D, 0 \mathrm{Ca}^{2+}$. 
A trPV4 B

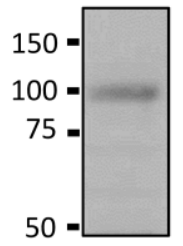

TRPV4

WGA
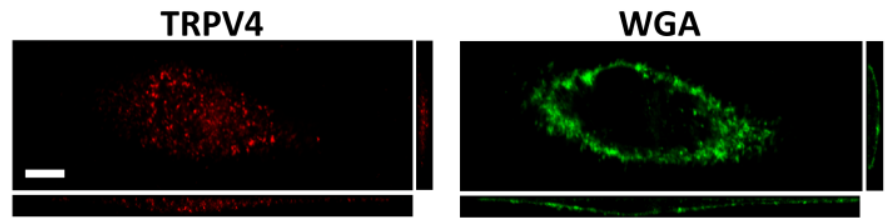

PM TRPV4

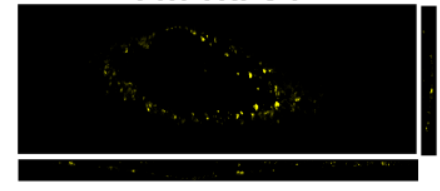

C

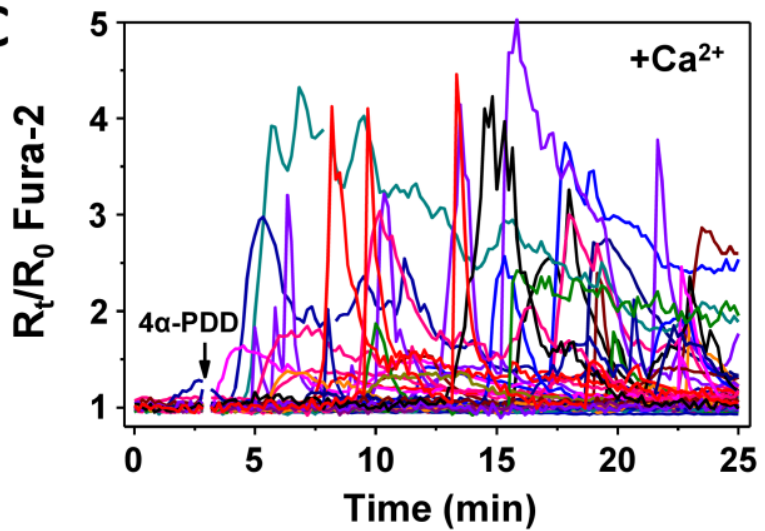

E

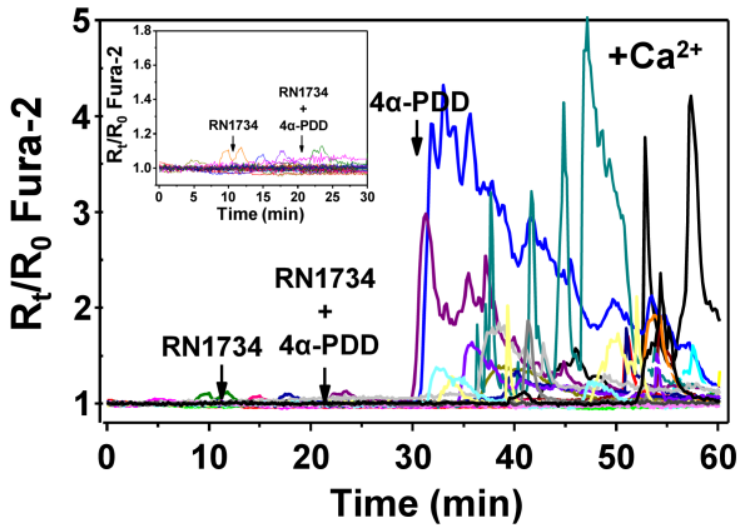

D

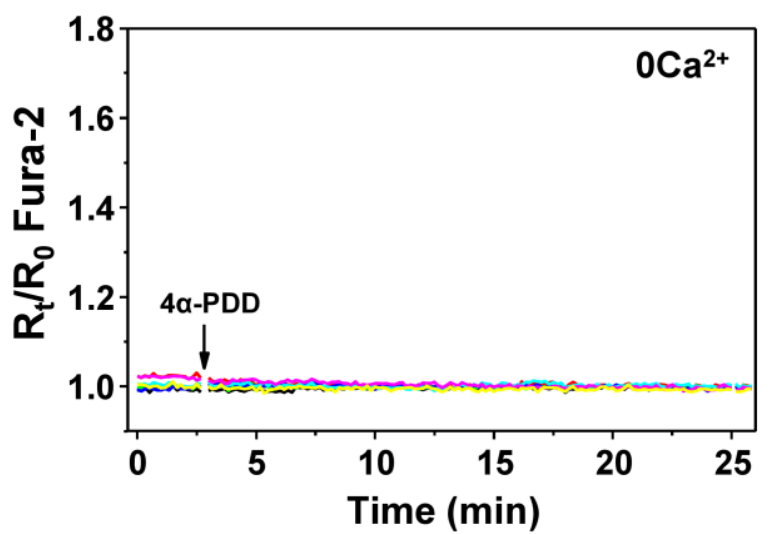

E

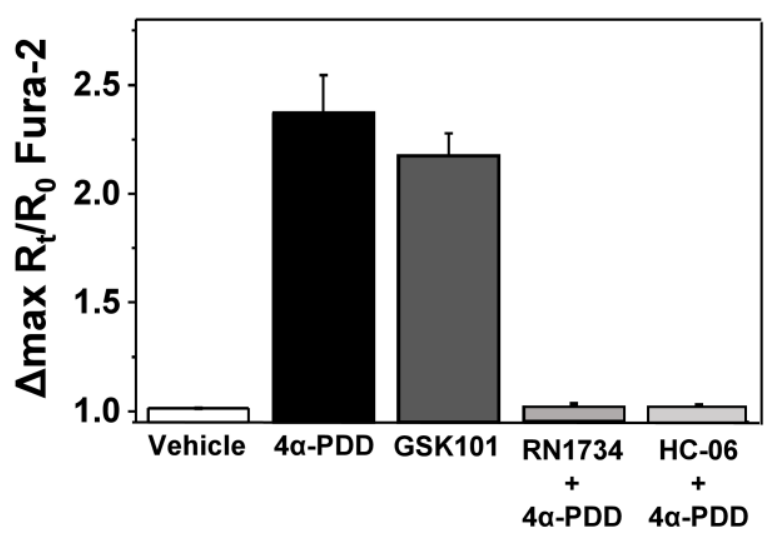

Figure 1 
A

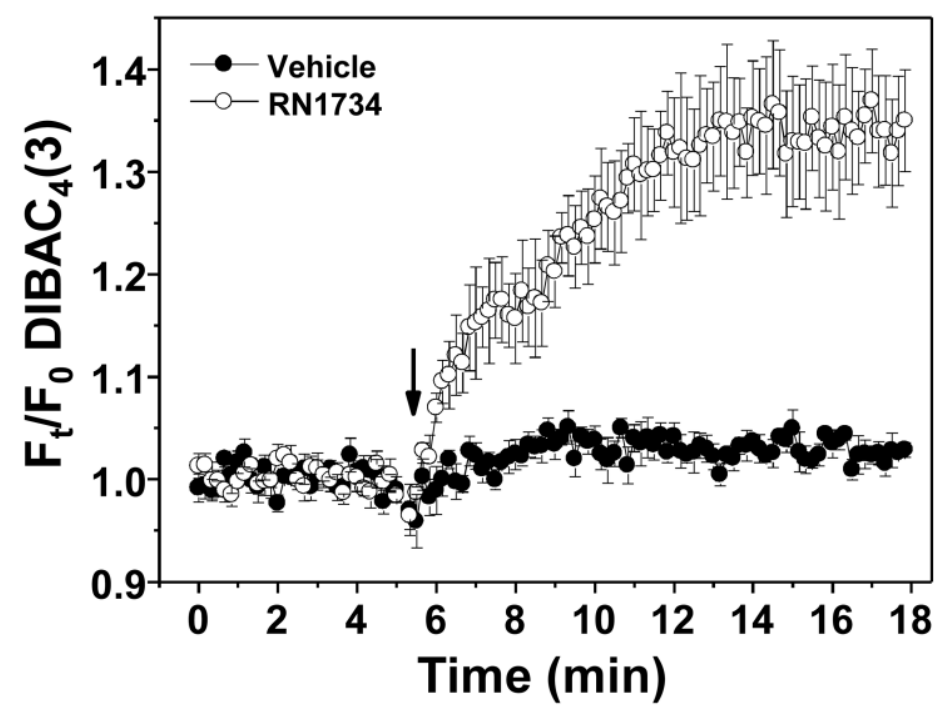

B

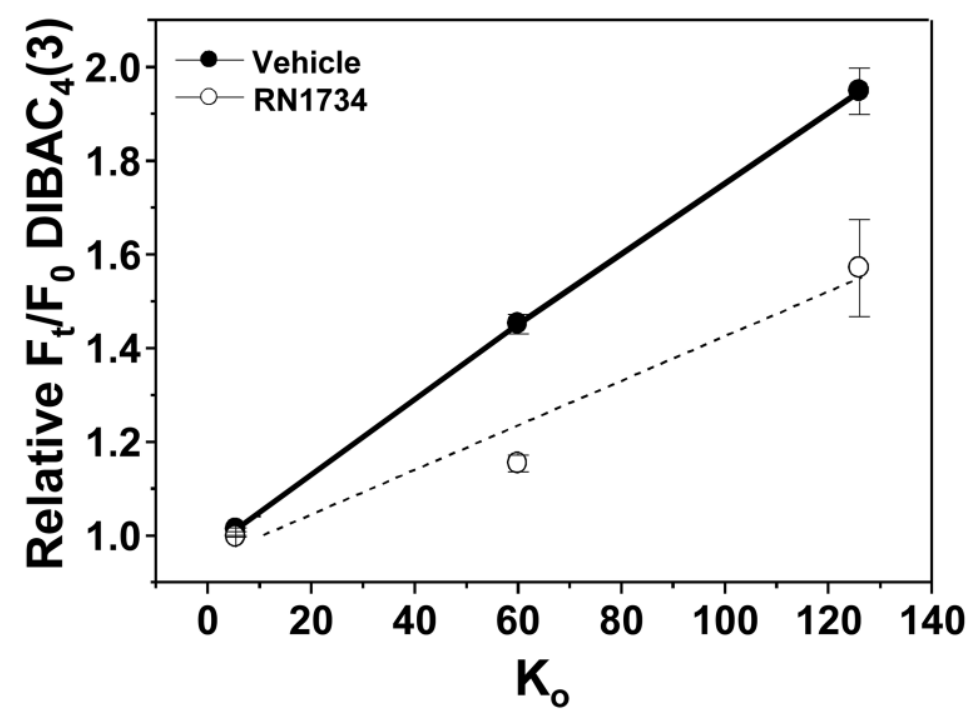

C

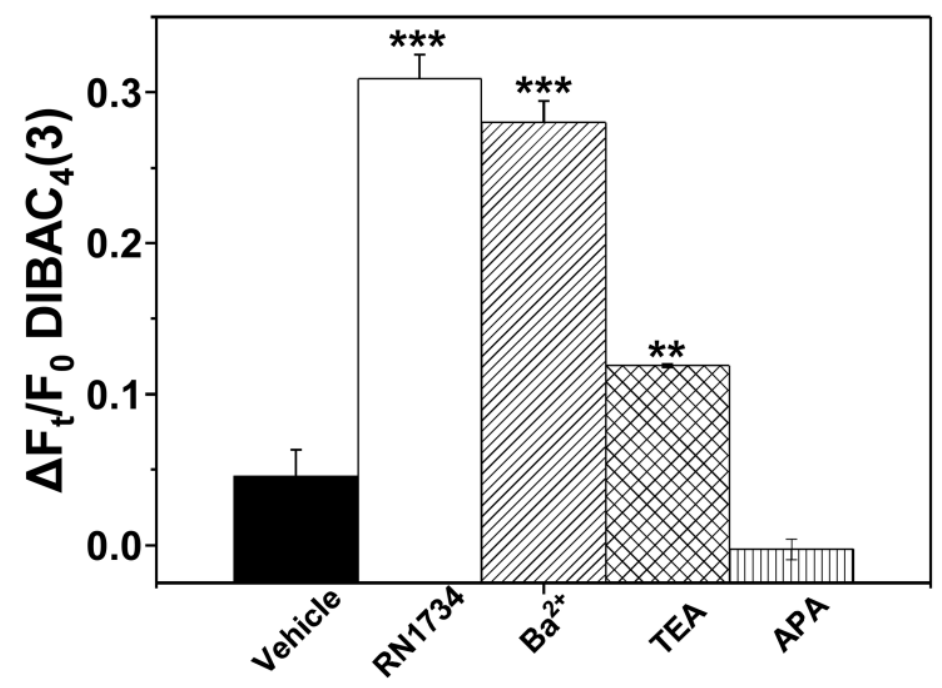

Figure 2 
A
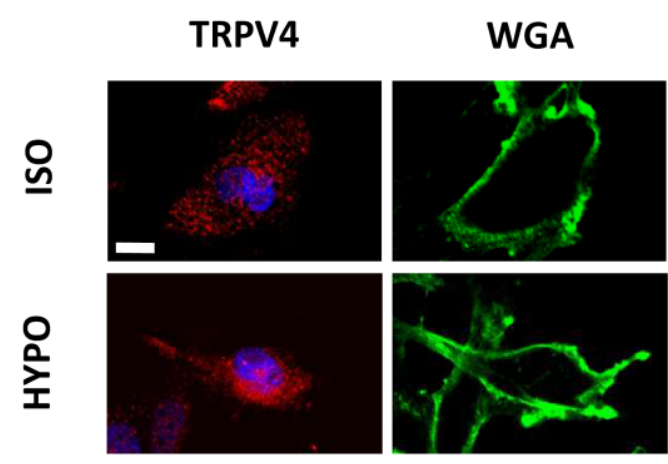

PM TRPV4

B

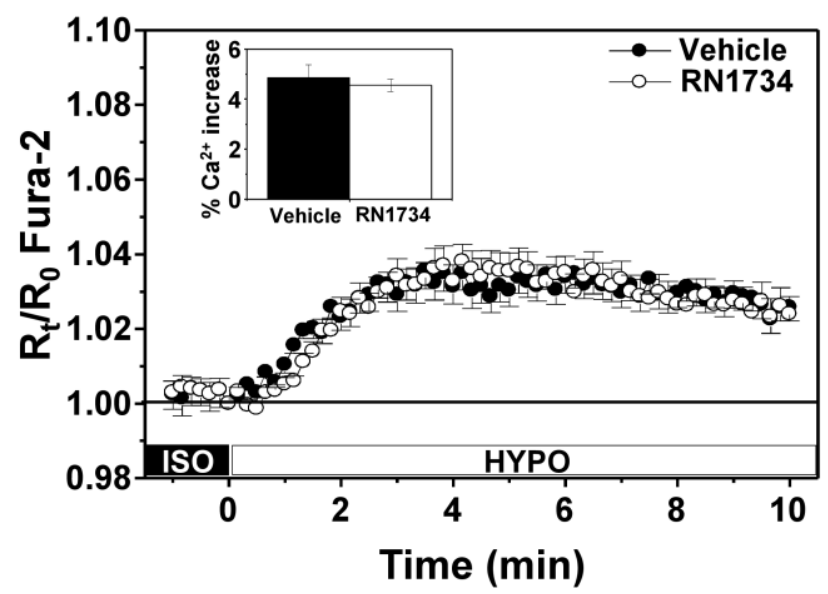

C

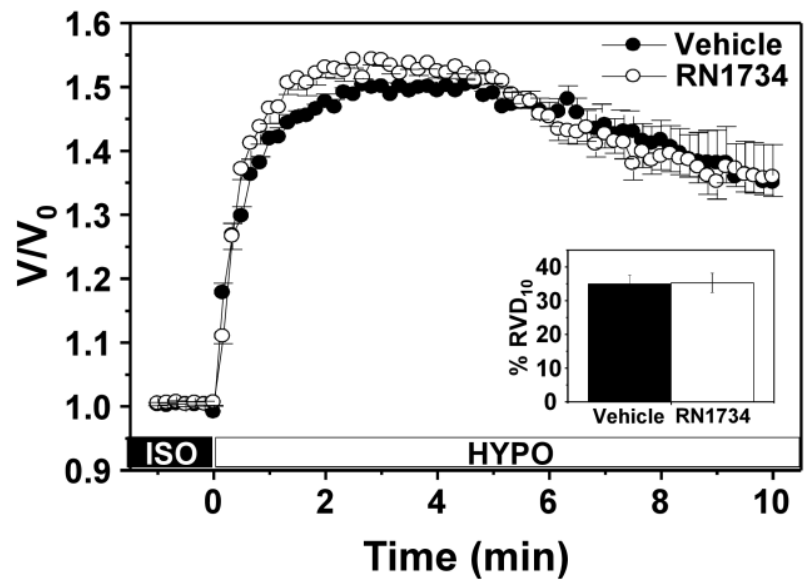

Figure 3 

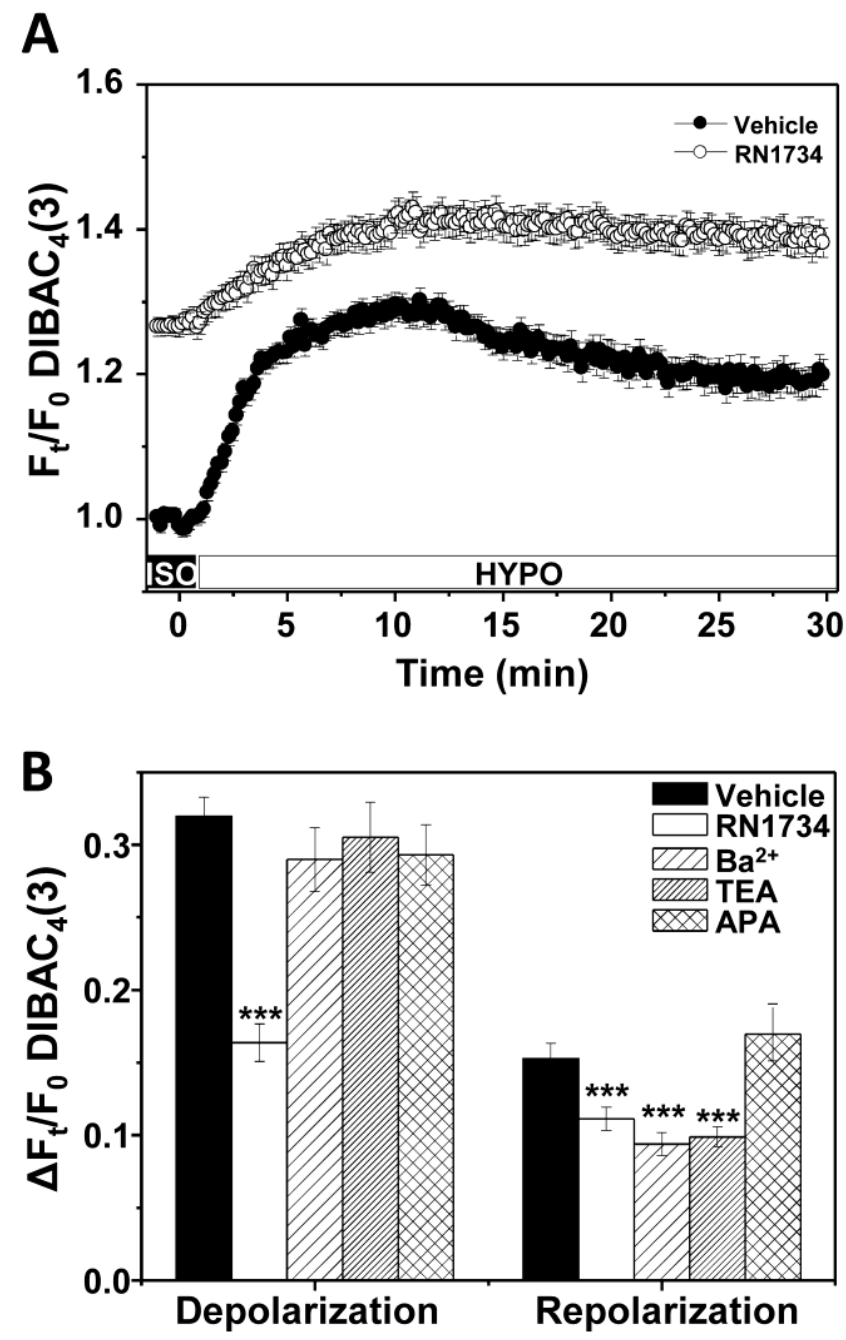

Figure 4 

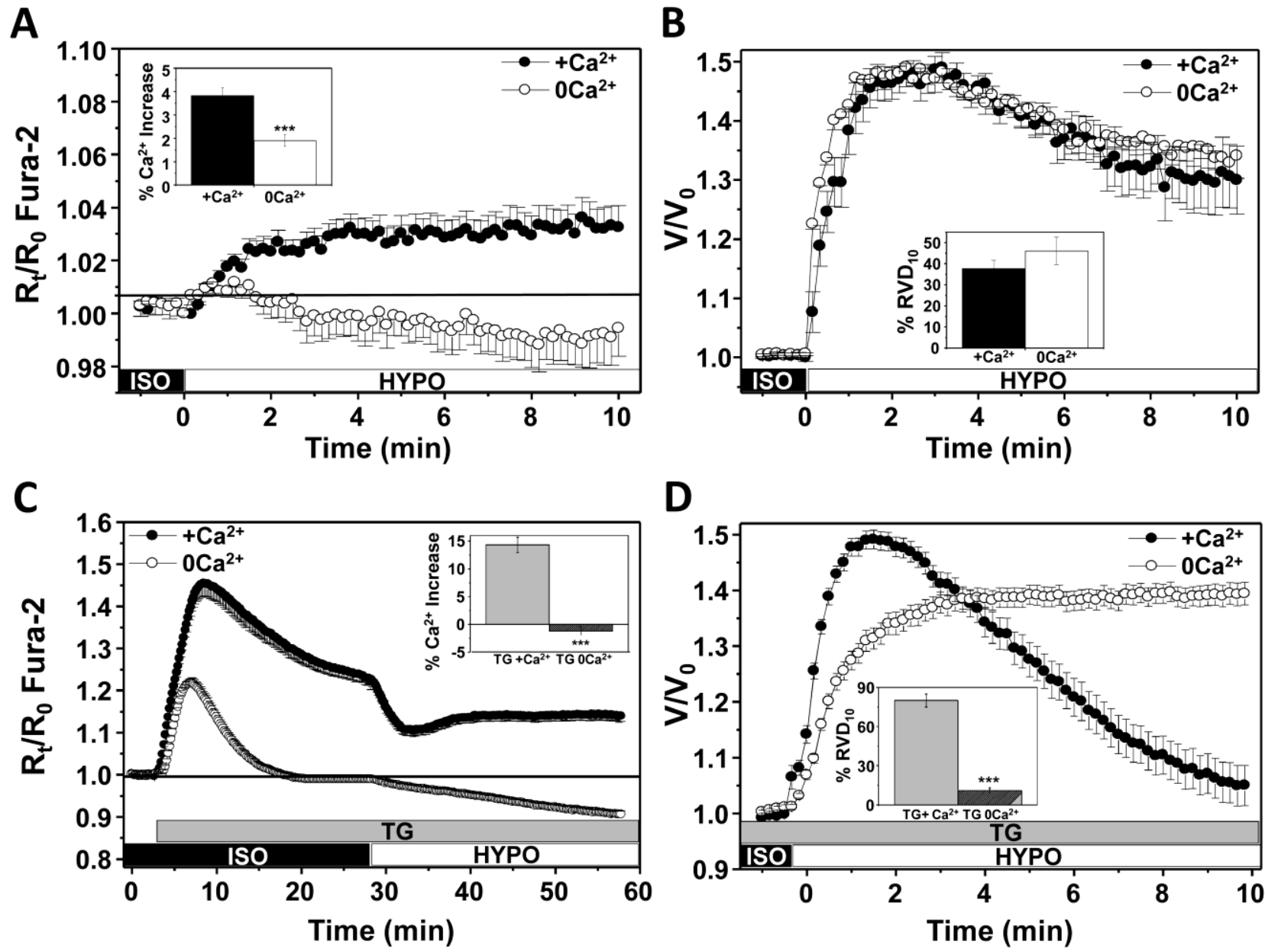

Figure 5 
A

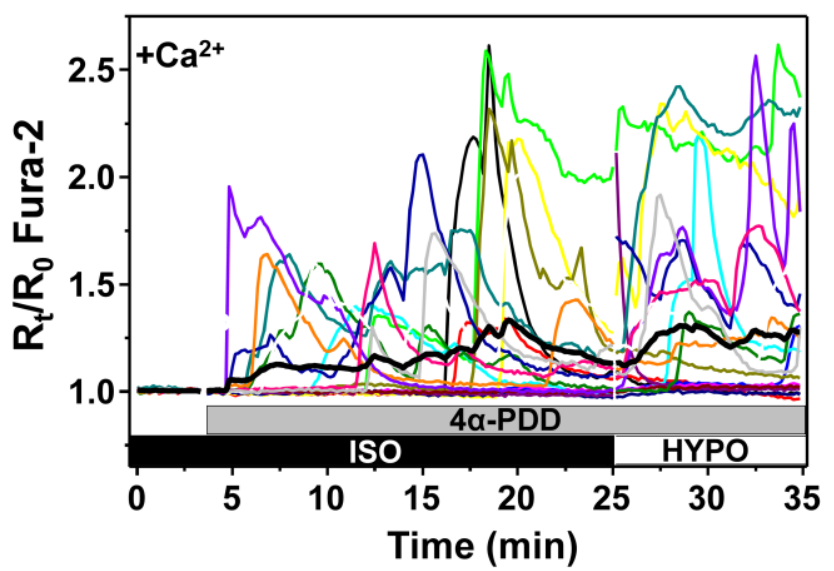

C

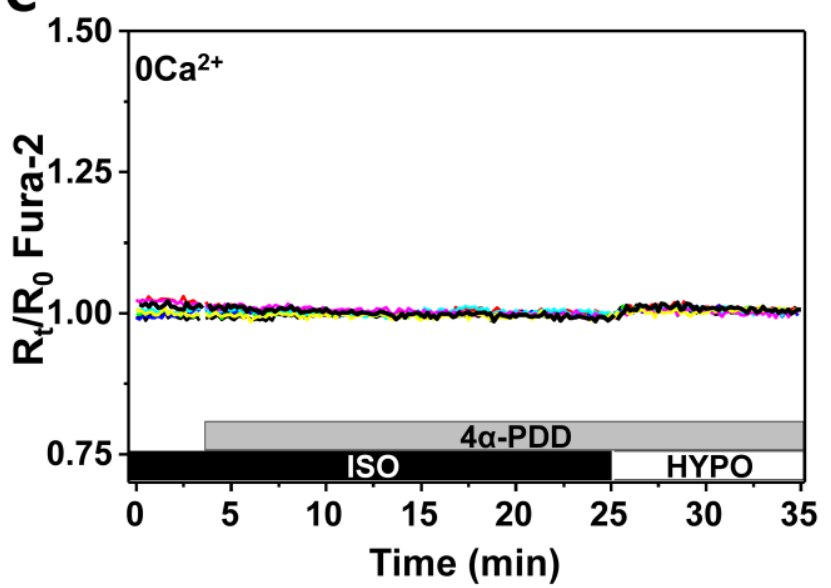

B

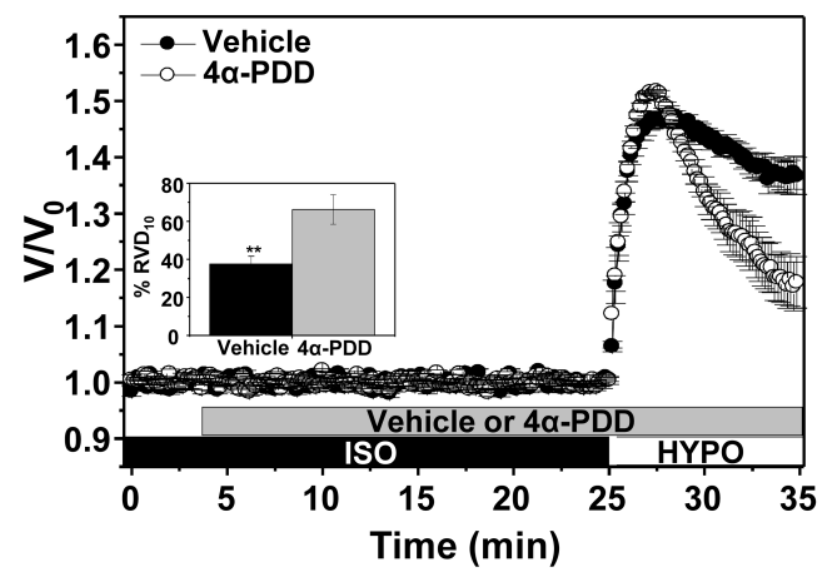

D

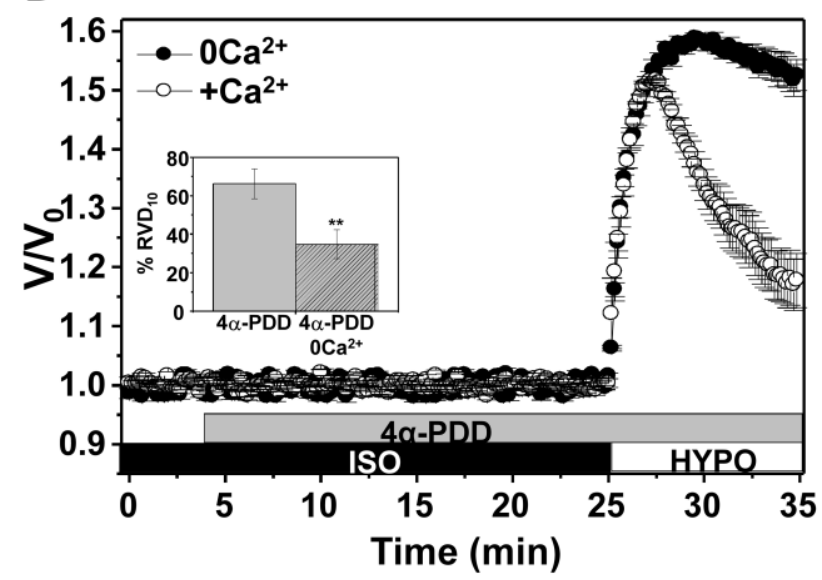

Figure 6 

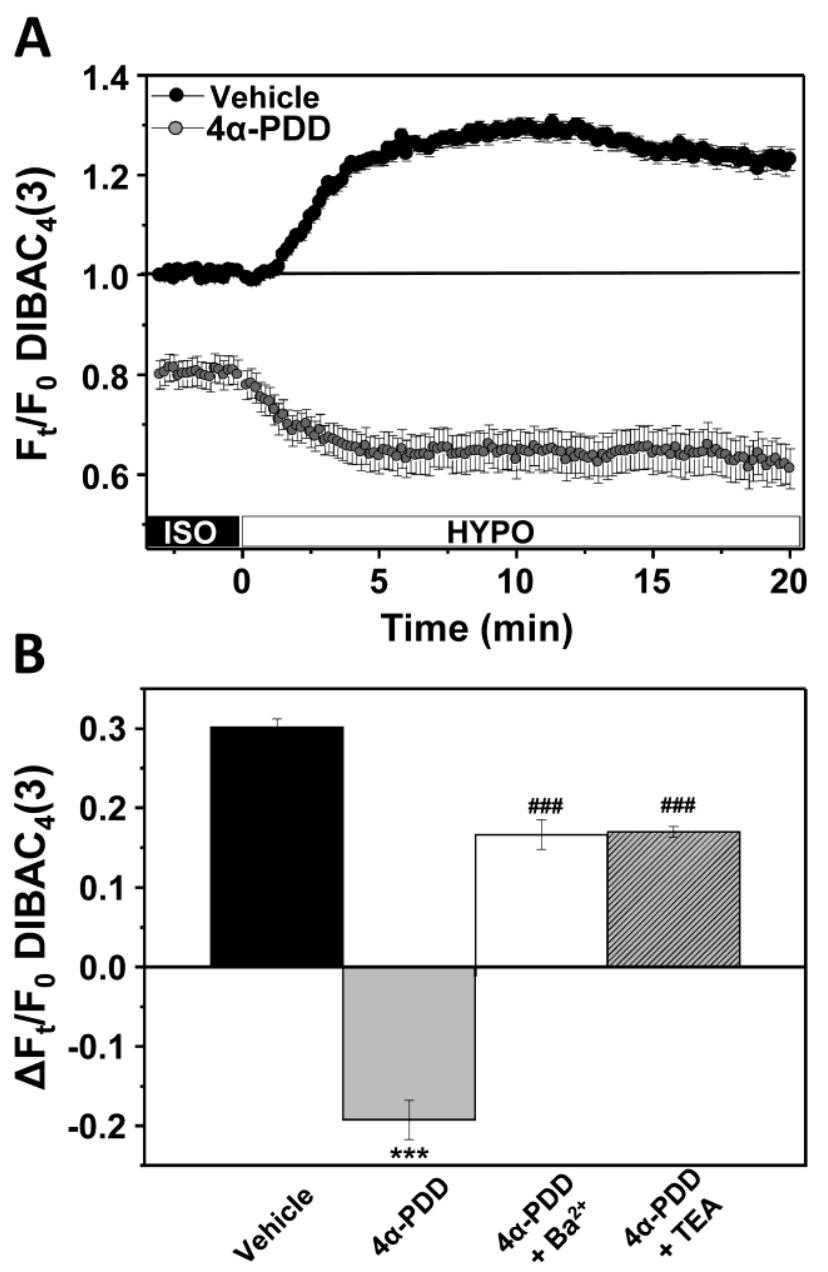

Figure 7 